\title{
Basal cell carcinoma. Diagnostic and therapeutic recommendations of the Polish Dermatological Society
}

\section{Rak podstawnokomórkowy skóry. Rekomendacje diagnostyczno-terapeutyczne Polskiego Towarzystwa Dermatologicznego}

\begin{abstract}
Aleksandra Lesiak', Joanna Czuwara², Grażyna Kamińska-Winciorek ${ }^{3}$, Dorota Kiprian4, Joanna Maj ${ }^{5}$, Witold Owczarek ${ }^{6}$, Waldemar Placek ${ }^{7}$, Lidia Rudnicka², Piotr Rutkowski ${ }^{8}$, Michał Sobjanek ${ }^{9}$, Małgorzata Sokołowska-Wojdyło" , Jacek Szepietowski ${ }^{5}$, Barbara Zegarska ${ }^{10}$, Wojciech Zegarski ${ }^{10}$
\end{abstract}

\footnotetext{
'Department of Dermatology, Paediatric Dermatology and Oncology Clinic, Medical University of Lodz, Poland

2Department of Dermatology, Medical University of Warsaw, Poland

${ }^{3}$ Department of Bone Marrow Transplantation and Haematology-Oncology, the Maria Skłodowska-Curie Memorial Cancer Centre and Institute of Oncology, Branch in Gliwice, Poland

${ }^{4}$ Head and Neck Cancer Clinic, the Maria Skłodowska-Curie Memorial Cancer Centre and Institute of Oncology in Warsaw, Poland

${ }^{5}$ Department of Dermatology, Venereology and Allergology, Medical University of Wroclaw, Poland

${ }^{6}$ Dermatology Clinic, Military Institute of Medicine in Warsaw, Poland

${ }^{7}$ Department of Dermatology, Sexually Transmitted Diseases and Clinical Immunology, University of Warmia and Mazury in Olsztyn, Poland

${ }^{8}$ Department of Soft Tissue/Bone Sarcoma and Melanoma, the Maria Skłodowska-Curie Memorial Cancer Centre and Institute of Oncology in Warsaw, Poland

${ }^{9}$ Department of Dermatology, Venereology and Allergology, Medical University of Gdansk, Poland

${ }^{10}$ Department of Cosmetology and Aesthetic Dermatology, Medical College in Bydgoszcz, Nicolaus Copernicus University in Torun, Poland

'Katedra i Klinika Dermatologii, Dermatologii Dziecięcej i Onkologicznej Uniwersytetu Medycznego w Łodzi, Polska

${ }^{2}$ Katedra i Klinika Dermatologiczna Warszawskiego Uniwersytetu Medycznego, Polska

${ }^{3}$ Klinika Transplantacji Szpiku i Onkohematologii Centrum Onkologii - Instytutu im. Marii Skłodowskiej-Curie, Oddział w Gliwicach, Polska

${ }^{4}$ Klinika Nowotworów Głowy i Szyi Centrum Onkologii - Instytutu im. Marii Skłodowskiej-Curie w Warszawie, Polska

${ }^{5}$ Katedra i Klinika Dermatologii, Wenerologii i Alergologii Uniwersytetu Medycznego we Wrocławiu, Polska

${ }^{6}$ Klinika Dermatologii Wojskowego Instytutu Medycznego w Warszawie, Polska

${ }^{7}$ Katedra i Klinika Dermatologii, Chorób Przenoszonych Drogą Płciową i Immunologii Klinicznej Uniwersytetu Mazursko-Warmińskiego w Olsztynie, Polska

${ }^{8}$ Klinika Nowotworów Tkanek Miękkich, Kości i Czerniaków Centrum Onkologii - Instytutu im. Marii Skłodowskiej-Curie w Warszawie, Polska

${ }^{9}$ Katedra i Klinika Dermatologii, Wenerologii i Alergologii Gdańskiego Uniwersytetu Medycznego, Polska

${ }^{10}$ Katedra Kosmetologii i Dermatologii Estetycznej Collegium Medicum w Bydgoszczy Uniwersytetu Mikołaja Kopernika w Toruniu, Polska
}

\author{
CORRESPONDING AUTHOR/ \\ ADRES DO KORESPONDENCJI: \\ prof. dr hab. n. med. \\ Aleksandra Lesiak \\ Katedra i Klinika Dermatologii, \\ Dermatologii Dziecięcej \\ i Onkologicznej \\ Uniwersytet Medyczny \\ w Łodzi \\ ul. Kniaziewicza 1/5 \\ 91-437 Łódź \\ tel.: +48 422516192 \\ e-mail: lesiak_ola@interia.pl
}

\begin{abstract}
Incidence of skin cancers is constantly increasing, what constitutes a significant epidemiologic problem of modern medicine. Basal cell carcinoma is the most common neoplasm affecting Caucasians. Histopathological examination is a gold standard that allows for diagnosing skin cancers. The presented recommendations discuss clinical and pathomorphological sub-types of basal cell carcinoma, their dermoscopic features, stage assessment, and methods for treatment as well as prevention of recurrence of this cancer. Surgical excision of the lesion is a basic and preferred therapeutic option. Other non-surgical options show lower treatment efficacy, and thus, should be considered in cases of cancers with low risk of recurrence, when a surgery is contraindicated or impossible.
\end{abstract}




\section{STRESZCZENIE}

Częstość zachorowań na raki skóry stale wzrasta, co stanowi istotny problem epidemiologiczny współczesnej medycyny. Rak podstawnokomórkowy skóry jest najczęstszym nowotworem występującym u rasy kaukaskiej. Złotym standardem w rozpoznawaniu raków skóry jest badanie histopatologiczne. W przedstawionych zaleceniach zostały omówione podtypy kliniczne i patomorfologiczne raka podstawnokomórkowego skóry, ich cechy dermoskopowe, ocena stopnia zaawansowania, a także metody leczenia i zapobiegania nawrotom tego nowotworu. Podstawową i preferowaną opcją terapeutyczną jest chirurgiczne wycięcie zmiany. Pozostałe metody - niechirurgiczne - cechują się niższymi wskaźnikami wyleczeń, dlatego powinny być rozważane w przypadku nowotworów o niskim ryzyku nawrotów, gdy zabieg chirurgiczny jest przeciwwskazany lub niemożliwy do przeprowadzenia.

Key words: diagnostics, treatment, basal cell carcinoma, recommendations.

Słowa kluczowe: diagnostyka, leczenie, rak podstawnokomórkowy, rekomendacje.

\section{INTRODUCTION}

In the last couple of years incidence of all non-melanoma skin cancers (NMSC) has been growing dynamically. Basal cell carcinoma (BCC) is the most common skin cancer and simultaneously the most popular malignant cancer affecting white people. Basal cell carcinoma is characterized by a usual slow progression, local malignancy and low mortality. Sometimes it may lead to considerable destruction of surrounding tissues and organs, and cartilage or even bone infiltration and deformation. Although BCC is characterized by a low risk of metastases (about $0.0028-0.5 \%$ of BCC cases [1]), it constitutes a significant social problem and contributes to considerable decrease in patients' quality of life - especially when one considers its clinical course, during which ugly lesions are often created on the skin being exposed to ultraviolet radiation (UV).

Due to weight of the problem, BCC diagnostics and therapy are important elements of clinical practice of dermatologists and venereologists, surgeons, and GPs. Choosing an appropriate treatment method after diagnosing BCC is a frequent and current topic of medical discussions. This paper, which discusses how to deal with patients with suspected and diagnosed BCC, has been prepared by an interdisciplinary group of experts of Polish Dermatological Society and includes modern literature data and guidelines of the American Academy of Dermatology (AAD, 2017) [2], current recommendation of National Comprehensive Cancer Network (2018) [3], and Polish multi-specialist recommendations [4].

\section{WPROWADZENIE}

W ostatnich latach częstość występowania wszystkich rodzajów raków skóry (non-melanoma skin cancers - NMSC) wzrasta dynamicznie. Rak podstawnokomórkowy (basal cell carcinoma - BCC) jest najczęstszym rakiem skóry, a także najczęstszym nowotworem złośliwym występującym u ludzi rasy białej. Charakteryzuje się zazwyczaj wolnym przebiegiem, miejscową złośliwością i niską śmiertelnością. Może niekiedy prowadzić do znacznych destrukcji otaczających tkanek i narządów, naciekania i deformacji chrząstek, a nawet kości. Choć BCC cechuje się niewielkim ryzykiem tworzenia przerzutów (ok. 0,0028-0,5\% przypadków BCC [1]), to ze względu na przebieg kliniczny, w którym często dochodzi do tworzenia szpecących zmian na skórze eksponowanej na działanie promieniowania ultrafioletowego (ultraviolet radiation - UV), stanowi istotny problem społeczny, gdyż przyczynia się do znacznego obniżenia jakości życia pacjentów.

Ze względu na rangę problemu diagnostyka i terapia BCC jest ważnym elementem praktyki klinicznej dermatologów-wenerologów, chirurgów i lekarzy rodzinnych. Wybór odpowiedniej metody leczniczej po zdiagnozowaniu BCC jest częstym i aktualnym tematem dyskusji medycznych. W niniejszym opracowaniu dotyczącym postępowania u pacjentów z podejrzeniem i rozpoznaniem BCC, przygotowanym przez interdyscyplinarną grupę ekspertów Polskiego Towarzystwa Dermatologicznego (PTD), uwzględniono współczesne dane z piśmiennictwa oraz wytyczne American Academy of Dermatology (AAD, 2017) [2], aktualne rekomendacje National Comprehensive Cancer Network (2018) [3] oraz polskie zalecenia wielospecjalistyczne [4]. 


\section{EPIDEMIOLOGY}

Skin cancers are the most common malignant tumours in the world [5]. In Caucasians the risk for skin cancer exceeds $20 \%$ and increases with age [6]. Basal cell carcinoma and squamous cell carcinoma (SCC) constitute the total of $99 \%$ of all NMSC cases, whereby BCC is diagnosed 3-5 times more often than SCC $[1,5,7]$.

Although the incidence rate for skin cancers is clearly the highest in Australia, more and more cases are reported in Europe and the United States [1]. Taking into account data of Polish National Cancer Registry it could be expressly stated that NMSC incidence rate increased considerably during the last 20 years in Poland. Skin cancer incidence in 2000 among women amount to over 2,700 new cases, and in men to over 2,600; in 2010 5,300 and 4,800 new cases were noted accordingly. It is almost a $100 \%$ increase in incidence within ten years [8]. According to the estimated data, this trend will persist in the coming years. In Poland in 2011 alone 5,408 NMSC cases were confirmed in men, and 6,031 in women, what gave a total of 11,439 new cases [6]. Probably the quoted numbers are understated since registration of new cases is incomplete.

\section{AETIOLOGY AND RISK FACTORS}

Aetiology of BCC development is complex. The most important aetiological factor of BCC development is excessive exposure to UV radiation. This fact is confirmed by data regarding BCC incidence depending on the latitude and typical location in body areas exposed to solar radiation [3]. A recent increase in BCC incidence is also associated with lifestyle changes, excessive and inappropriate sunbathing, ways of dressing, and using lamps that emit UV radiation (so-called tanning salons). People working in the open air, professionally and chronically subject to UV radiation, who fail to use any forms of photoprotection, constitute a group that is especially at risk of developing a skin cancer [9]. Furthermore, an intense exposure to sun in childhood appears to be of key important for BCC development in adulthood [10]. Other important carcinogens include ionizing radiation, arsenic, and polycyclic aromatic hydrocarbons.

Phenotypic traits such as fair skin, red or blonde hair, and bright eye colour are also independent risk factors [3]. Phenotypes I and II in the Fitzpatrick scale are considered to predispose people to develop BCC more than other phenotypes. Additional risk factors for skin cancer development are radiation therapy, chronic immunosuppression, HIV infections (human immunodeficiency virus), and HPV infections (human papilloma virus) $[3,10,11]$. Basal cell carcinoma

\section{EPIDEMIOLOGIA}

Raki skóry są najczęstszymi nowotworami złośliwymi występującymi na świecie [5]. U osób rasy kaukaskiej ryzyko zachorowania na raka skóry przekracza 20\% i wzrasta z wiekiem [6]. Rak podstawnokomórkowy i rak kolczystokomórkowy (squamous cell carcinoma - SCC) stanowią łącznie nawet 99\% wszystkich NMSC, przy czym BCC jest rozpoznawany 3-5 razy częściej niż SCC $[1,5,7]$.

Wskaźnik zapadalności na raki skóry jest zdecydowanie najwyższy w Australii, ale coraz więcej zachorowań notuje się w Europie oraz Stanach Zjednoczonych [1]. Opierając się na danych polskiego Krajowego Rejestru Nowotworów (KRN), można jednoznacznie stwierdzić, że w ciągu ostatnich 20 lat w Polsce znacznie wzrósł współczynnik zachorowalności na NMSC. W 2000 roku odnotowano ponad 2700 nowych zachorowań na raki skóry wśród kobiet i ponad 2600 wśród mężczyzn, natomiast w 2010 roku odpowiednio 5300 oraz 4800 nowych przypadków. Oznacza to niemal 100-procentowy wzrost zachorowalności w ciągu 10 lat [8]. Według szacunków trend wzrostowy utrzyma się także w kolejnych latach. W 2011 roku w Polsce stwierdzono 5408 przypadków NMSC u mężczyzn oraz 6031 u kobiet, co łącznie dało 11439 nowych zachorowań [6]. Prawdopodobnie przytoczone liczby są zaniżone w związku z niepełną rejestracją nowych przypadków.

\section{ETIOLOGIA I CZYNNIKI RYZYKA}

Etiologia rozwoju BCC jest złożona. Najważniejszym czynnikiem etiologicznym jest nadmierna ekspozycja na promieniowanie UV. Potwierdzają to dane dotyczące zapadalności na BCC w zależności od szerokości geograficznej oraz typowa lokalizacja zmian w okolicach ciała eksponowanych na promieniowanie słoneczne [3]. Wzrost zachorowalności na BCC $\mathrm{w}$ ostatnich latach wiąże się ponadto ze zmianą stylu życia, nadmiernym i nieprawidłowym opalaniem, zmianą sposobu ubierania, stosowaniem lamp emitujących promieniowanie UV (tzw. solariów). Osoby pracujące poza pomieszczeniami zamknięty$\mathrm{mi}$, przewlekle poddane działaniu promieniowania UV, niekorzystające z żadnej formy fotoprotekcji stanowią grupę szczególnie narażoną na występowanie raków skóry [9]. Ponadto intensywna ekspozycja na słońce $\mathrm{w}$ dzieciństwie ma istotne znaczenie dla rozwoju BCC w dorosłym życiu [10]. Ważnymi kancerogenami są też promieniowanie jonizujące, arsen $i$ aromatyczne związki policykliczne.

Cechy fenotypowe, takie jak jasna skóra, rude lub blond włosy, jasny kolor oczu, są również niezależnymi czynnikami ryzyka [3]. Uznaje się, że fototypy I i II wg skali Fritzpatricka bardziej predysponują do rozwoju BCC niż pozostałe. Dodatkowe czynniki ryzyka to 
develops also in long-lasting scar tissue, non-healing fistulae, ulcerations, burns, and chronically irritated skin with signs of dermatitis [12].

Moreover, genetic factors contribute to BBC development $[3,10]$. Research on Gorlin-Goltz syndrome (nevoid basal cell carcinoma syndrome, NBCCS) - a genetic autosomal dominant condition caused by mutation of PTCH1 gene locus (9q22.3) characterized by occurrence of multiple BCC cases - contributed to defining a considerable role of hedgehog pathway in development of this cancer [13]. Hedgehog pathway has an important regulatory function in embryonic development, whereas in an adult organism it participates in controlling health tissues responsible for development of some neoplasms, including BCC. In the majority of sporadic $B C C$ forms, an excessive activation of this pathway occurs by inactivation of PTCH1 receptor (Patched 1) in 90\% of cases, or by oncogenic activation of SMO receptor (Smoothened) in 10\% of cases [14]. Furthermore, other genetic syndromes may predispose people to develop NMSC, including xeroderma pigmentosum, epidermolysis bullosa, Ferguson-Smith syndrome, Muir-Torre syndrome, Bazex syndrome, and Rombo syndrome [3,4].

\section{CLINICAL PRESENTATION AND CLINICAL TYPES}

Typical BCC clinical presentation is a pink lamella, papula or nodule that is elevated and pearlyshaped or has an opalescent and translucent surface in cases of a nodule. As the cancer progresses, its surface may become covered in small erosions, eschars or ulcers. Basal cell carcinoma clinical types encompass superficial BCC, nodular BCC, pigmented BCC, morpheaform BCC, and ulcerative BCC that is the most destructive for the surrounding tissues. Clinical differential diagnostic of BCC involves a number of disease entities, including actinic keratosis, Bowen's disease, seborrhoeic keratosis, dermomycosis, nummular eczema, psoriasic focus, discoid lupus erythematosus (DLE), scar tissue, lupus vulgaris, cutaneous adnexal neoplasms originating in hair follicles, sebaceous and sudoriparous glands, and amelanotic melanoma. Dermoscopy is helpful in differential diagnostics as it reveals characteristic features of BCC (figs. 1-3).

The most common BCC clinical types are: nodular (21\%), superficial (17\%), micronodular (14\%), infiltrative $(7.5 \%)$, and morpheaform (1\%). Approximately one-third of all BCC, especially the recurrent ones, is of a mixed histological type.

Morpheaform BCC requires differential diagnostics against desmoplastic adnexal tumours, desmoplastic melanoma, and microcystic adnexal carcinoma. radioterapia, przewlekła immunosupresja, zakażenie ludzkim wirusem upośledzenia odporności (human immunodeficiency virus - HIV) oraz onkogennymi wirusami brodawczaka ludzkiego (human papilloma virus - HPV) [3, 10, 11]. Rak podstawnokomórkowy skóry powstaje także na podłożu długotrwałych blizn, niegojących się przetok, owrzodzeń, oparzeń i przewlekle drażnionej, zapalnie zmienionej skóry [12].

Do rozwoju BCC przyczyniają się również czynniki genetyczne $[3,10]$. Badania nad zespołem Gorlina-Goltza (nevoid basal cell carcinoma syndrome - NBCCS) - uwarunkowaną genetycznie chorobą dziedziczoną autosomalnie dominująco, spowodowaną mutacją w genie PTCH1 w locus 9q22.3, charakteryzującą się występowaniem mnogich przypadków BCC, posłużyły do ustalenia znaczącej roli szlaku Hedgehog w rozwoju tego raka [13]. Szlak Hedgehog pełni istotną funkcję regulatorową w rozwoju embrionalnym, natomiast $\mathrm{w}$ dojrzałym organizmie bierze udział w kontroli nad zdrowymi tkankami, odpowiadając za rozwój niektórych nowotworów, w tym BCC. W większości sporadycznych postaci BCC dochodzi do nadmiernej aktywacji tego szlaku poprzez inaktywację receptora PTCH1 (Patched 1) (w 90\% przypadków) lub poprzez onkogenną aktywację receptora SMO (Smoothened) (w 10\%) [14]. Ponadto inne zespoły genetyczne mogą predysponować do powstania NMSC, m.in. skóra pergaminowata i barwnikowa (xeroderma pigmentosum), pęcherzowe oddzielanie się naskórka, zespół Fergusona-Smitha, zespół Muira-Torre’a, zespół Bazexa i zespół Rombo [3, 4].

\section{OBRAZ KLINICZNY I ODMIANY KLINICZNE}

Typowy obraz kliniczny BCC to blaszka, grudka lub guzek różowej barwy z uniesionym, perełkowatym wałem lub opalizująca, przezroczystą powierzchnią w przypadku guzka. Z czasem powierzchnia raka pokrywa się drobnymi nadżerkami, strupami lub ulega owrzodzeniu. Rak podstawnokomórkowy skóry występuje w postaci powierzchownej, guzkowej, barwnikowej, twardzinopodobnej oraz wrzodziejącej, która jest najbardziej destrukcyjna dla otaczających tkanek. Kliniczna diagnostyka różnicowa BCC obejmuje wiele jednostek chorobowych, w tym rogowacenie słoneczne, chorobę Bowena, brodawkę łojotokową, grzybicę skóry, wyprysk pieniążkowaty, ognisko łuszczycy, przewlekłą odmianę skórnego tocznia rumieniowatego (discoid lupus erythematosus - DLE), bliznę, gruźlicę toczniową, guzy pochodzące z przydatków z mieszków włosowych, gruczołów łojowych i potowych oraz czerniaka bezbarwnikowego. W diagnostyce różnicowej pomocne jest badanie dermoskopowe, które wykazuje charakterystyczne cechy BCC (ryc. 1-3). 

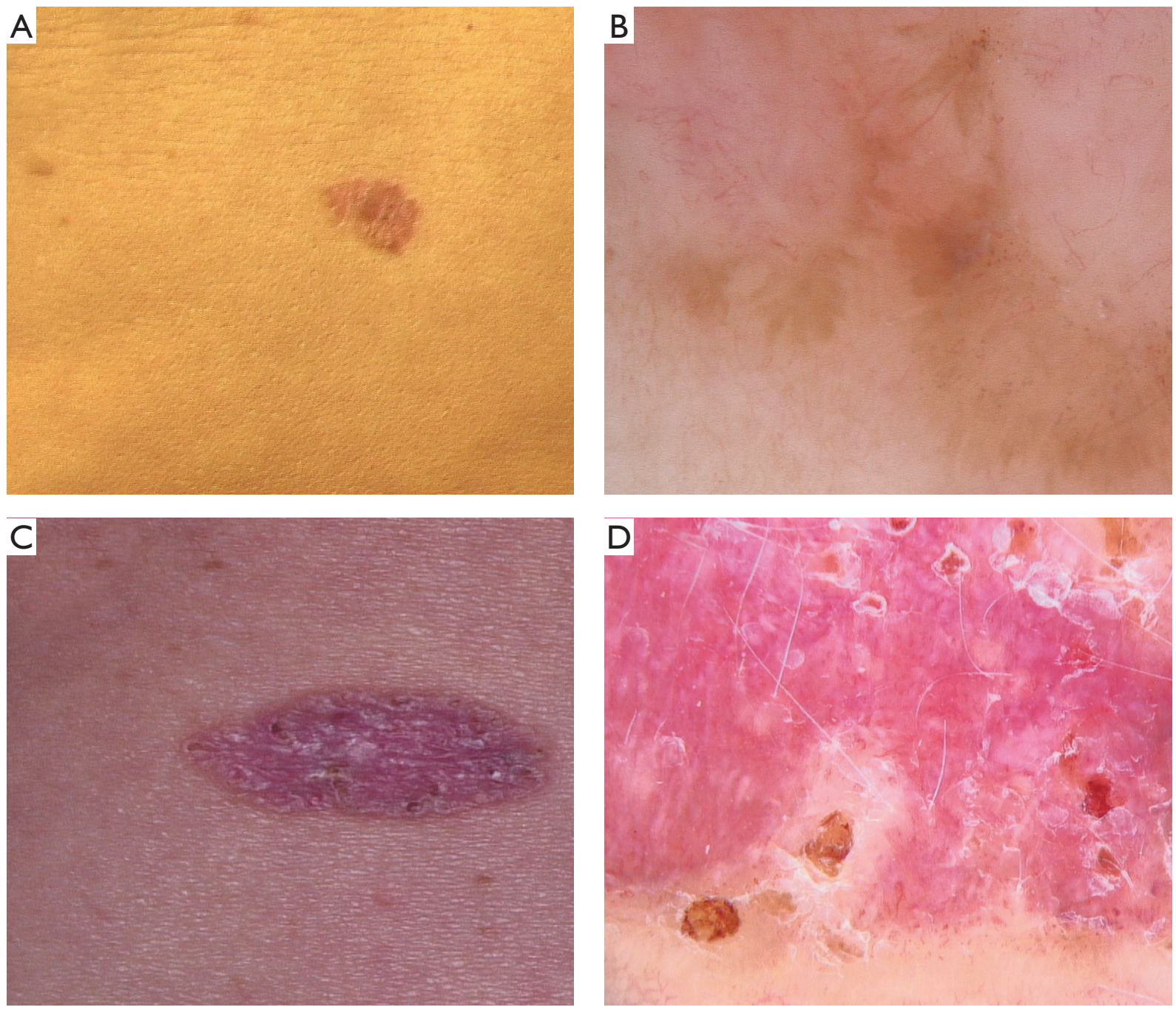

Figure I. A, C - Clinical presentation of superficial BCC. B - Pigmented variant of a superficial type in dermoscopy: maple leaf-like structures and numerous fine telangiectasias. D - In dermoscopy: white and pink homogenous areas, numerous glittering white lamellae and glittering streaks as well as numerous small erosions covered in eschars

Rycina I. A, C - Obraz kliniczny BCC, odmiana powierzchowna. B - Dermoskopia - wariant barwnikowy odmiany powierzchownej: struktury palczaste przypominające liście klonu oraz liczne, cienkie teleangiektazje. D - Dermoskopia - białoróżowe pola homogenne, liczne lśniące, białe blaszki i lśniące pasma oraz liczne drobne nadżerki pokryte strupem

Ulcerative BCC always requires histopathological diagnostics as other malignant skin cancers or metastases may resemble squamous cell carcinoma, Merkel cell carcinoma, porocarcinoma, sebaceous carcinoma, and metastases from thyroid or kidney cancer.

Basal cell carcinoma diagnosis, regardless of planned treatment method, should be based on clinical examination, dermoscopy, and a confirmed histological examination of the diagnostic or excision biopsy taken to determine the BCC type. Histological BCC form is of key importance for choosing an appropriate therapeutic option.

\section{HISTOLOGICAL TYPES}

Transformed BCC cells originate in basal epithelial cells of hair follicles, bulge areas of anagen
Najczęstsze typy kliniczne BCC to kolejno: guzkowy $(21 \%)$, powierzchowny $(17 \%)$, mikroguzkowy $(14 \%)$, naciekający $(7,5 \%)$ i twardzinopodobny $(1 \%)$. Około 1/3 BCC, zwłaszcza nawrotowych, ma mieszany typ histologiczny.

Twardzinopodobny typ BCC wymaga diagnostyki różnicowej z desmoplastycznymi guzami przydatkowymi, desmoplastycznym czerniakiem oraz drobnotorbielowatym rakiem przydatkowym (microcystic adnexal carcinoma).

Wrzodziejąca odmiana BCC wymaga zawsze diagnostyki histopatologicznej, ponieważ inne złośliwe nowotwory skóry lub przerzuty mogą wyglądać podobnie, np. SCC, rak z komórek Merkla, rak potowy, rak łojowy, przerzuty raka tarczycy czy raka nerki.

Rozpoznanie BCC, niezależnie od planowanej metody leczenia, powinno być oparte na badaniu klinicz- 

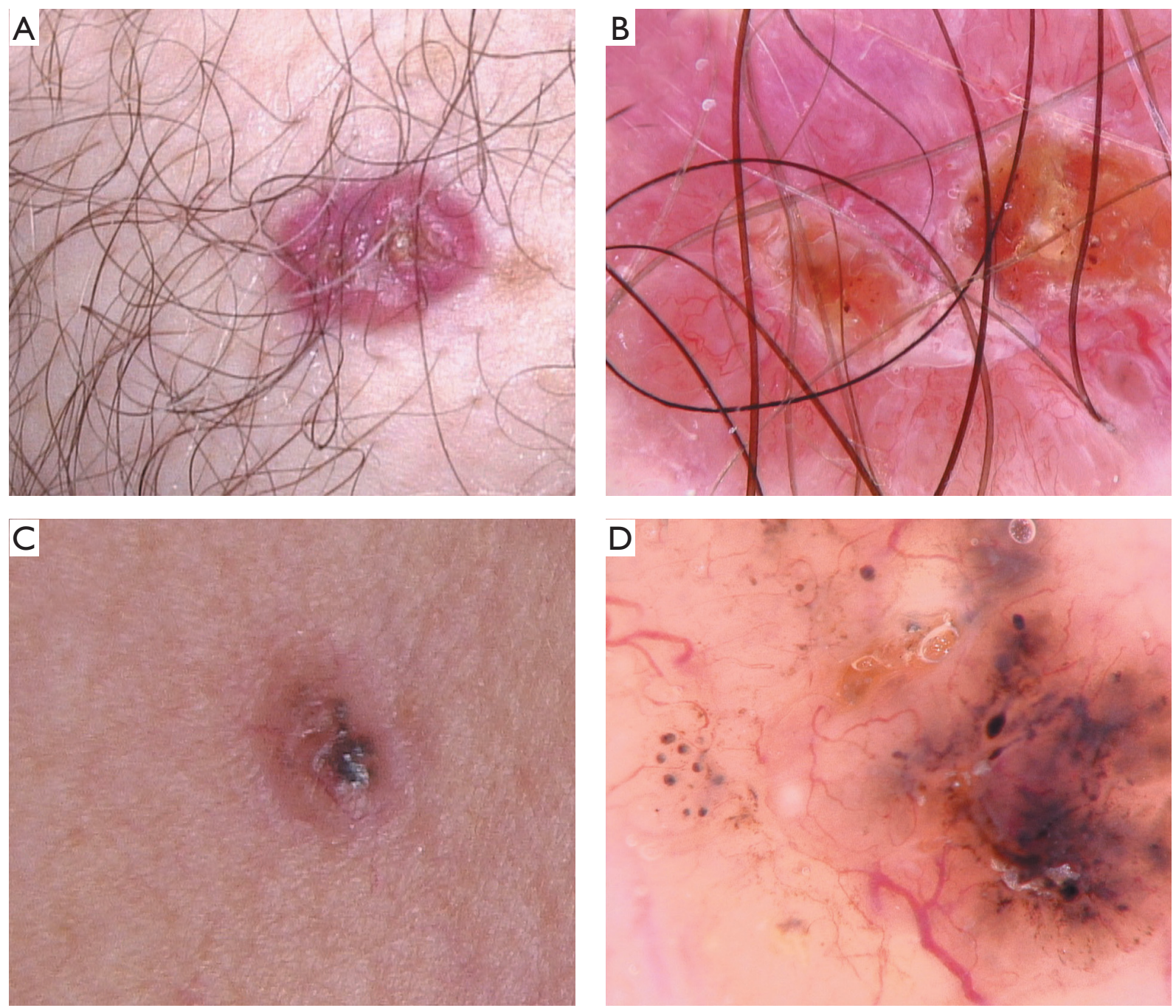

Figure 2. A - Clinical presentation of nodular BCC (non-pigmented). B - Nodular non-pigmented BCC in dermoscopy: numerous arborizing vessels with large vessel calibre, large central ulceration, visible glittering white lamellae and glittering streaks. C - Clinical presentation of nodular pigmented BCC. D - Nodular pigmented BCC in dermoscopy: visible all pigmented structures: grey and blue ovoid nests, grey and blue granules and bodies, pigmented structures with a spoke-wheel pattern, at the circumference there are visible maple-leaf structures; moreover, arborizing vessels with large calibre

Rycina 2. A - Obraz kliniczny BCC, odmiana guzkowa (bezbarwnikowa). B - Dermoskopia BCC, wariant guzkowy bezbarwnikowy - liczne naczynia drzewkowate o dużym kalibrze, duże centralne owrzodzenie, widoczne liczne lśniące, białe blaszki i lśniące pasma. C - Obraz kliniczny BCC, odmiana guzkowa barwnikowa. D - Dermoskopia BCC, odmiana guzkowa barwnikowa - widoczne wszystkie struktury barwnikowe: szaroniebieskie gniazda owalne, szaroniebieskie ziarnistości i ciałka, struktury barwnikowe typu koła ze szprychami, na obwodzie widoczne struktury palczaste przypominające liście klonu; ponadto naczynia drzewkowate o dużym kalibrze

hair, hair matrix cells or pluripotent epidermal cells. Due to that cells may show varied differentiation towards hair follicles, sebaceous glands, eccrine glands or apocrine glands. There are many histological BCC types depending on cytological features and differentiation features of tumour cells (BCC adnexogenes), however, they are characterized by dark purple colour of the cells at the nodule's rim and their palisade arrangement (fig. 4). Nevertheless, the most important division is based on the BBC nodule's growth, which determines the way in which the dermis is infiltrated. Biologically and prognostically, the architecture of a nodule's growth condi- nym, badaniu dermoskopowym i potwierdzone badaniem histologicznym materiału pobranego metodą biopsji diagnostycznej lub wycinającej w celu określenia typu BCC. Postać histologiczna tego nowotworu ma istotne znaczenie dla wyboru właściwej opcji terapeutycznej.

\section{TYPY HISTOLOGICZNE}

Komórki BCC wywodzą się z podstawnych komórek nabłonka mieszka włosowego okolicy wybrzuszenia włosów anagenowych, komórek macierzy włosa lub pluripotencjalnych komórek naskórka. 

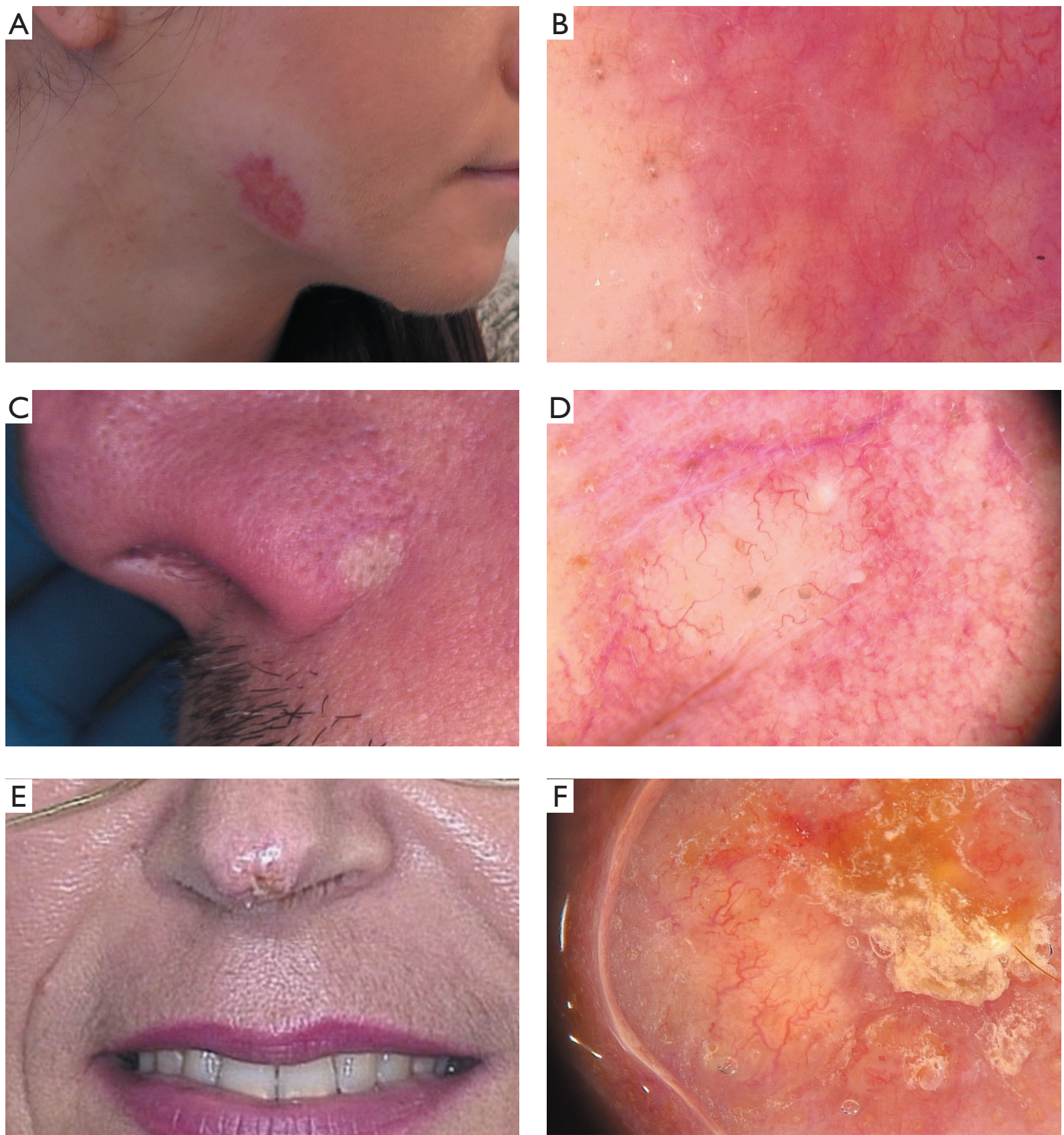

Figure 3. A - Clinical presentation of infiltrative BCC. B - Infiltrative BCC in dermoscopy: numerous, dispersed fine arborizing vessels with a tendency to create smaller branches; yellow and red background. C - Clinical presentation of morpheaform BCC. D - Morpheaform BCC in dermoscopy: numerous fine arborizing vessels and porcelain white glittering background. $\mathrm{E}$ - Clinical presentation of basosquamous cell carcinoma. F - Basosquamous cell carcinoma in dermoscopy: BCC dermoscopic traits - numerous arborizing vessels, and SCC - hyperkeratosis, white homogenous areas, layered keratin masses

Rycina 3. A - Obraz kliniczny BCC w odmianie naciekającej. B - Dermoskopia BCC, odmiana naciekająca - liczne rozproszone, cienkie naczynia drzewkowate z tendencją do tworzenia mniejszych rozgałęzień, żółto-czerwone podłoże. C - Obraz kliniczny BCC, odmiana twardzinopodobna. D - Dermoskopia BCC, odmiana twardzinopodobna - liczne cienkie naczynia drzewkowate i porcelanowobiałe, Iśniące podłoże. E - Obraz kliniczny raka podstawno-kolczystokomórkowego. F - Dermoskopia raka podstawno-kolczystokomórkowego: cechy dermoskopowe BCC - liczne naczynia drzewkowate oraz SCC - hiperkeratoza, białe, homogenne obszary, nawarstwione masy keratynowe

tions its clinical course. Thus, there are described the following histological BCC types: nodular (fig. 4 A), superficial (fig. 4 B), micronodular (fig. 4 C), and infludibulocystic that constitute a slowly progressing group, and an aggressive group, which includes
Z tego powodu komórki te mogą wykazywać różnorodne różnicowanie w kierunku struktur mieszka włosowego, gruczołów łojowych, ekrynowych i apokrynowych. Wyróżnia się wiele typów histologicznych BCC w zależności od cech cytologicznych 

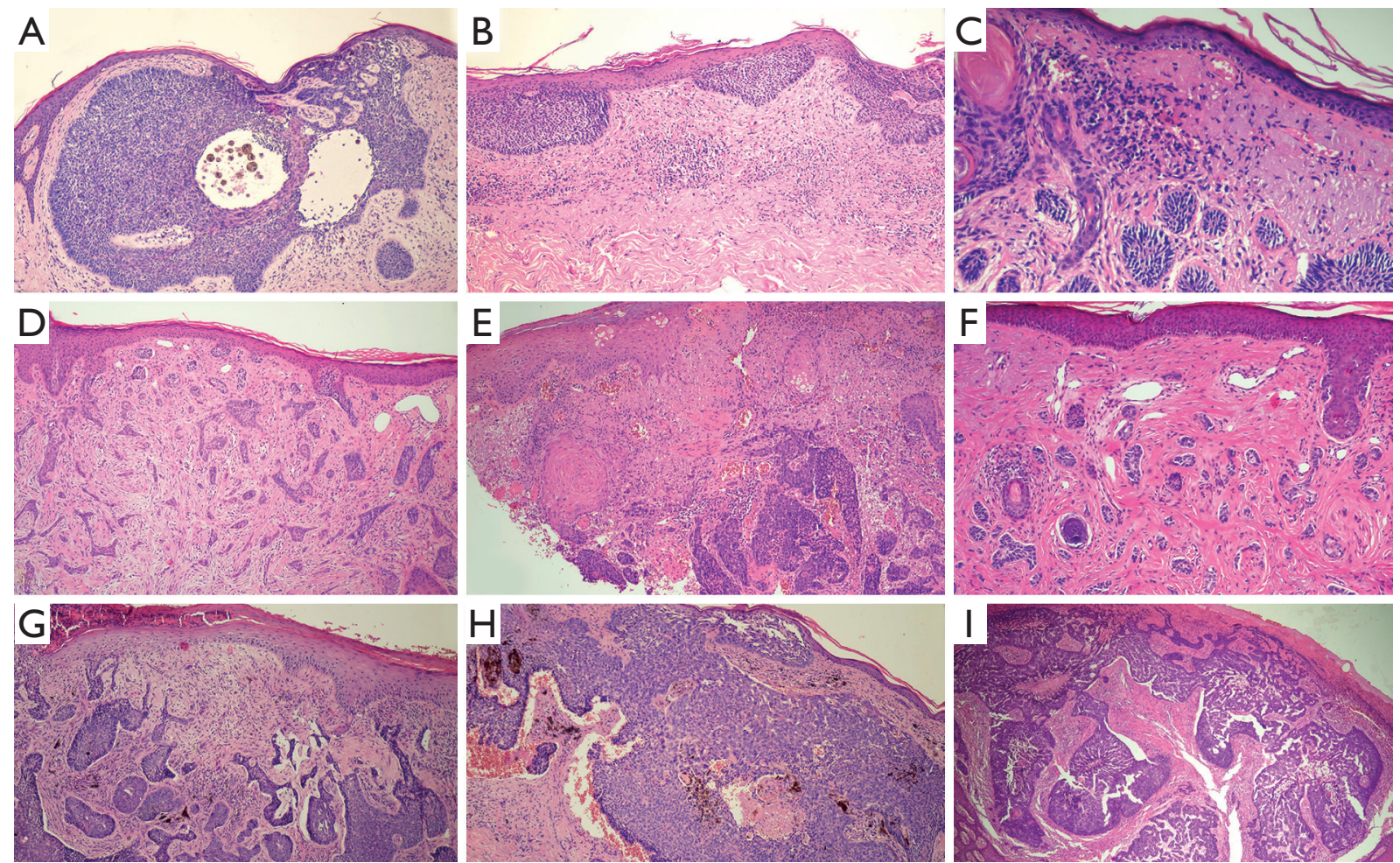

Figure 4. Histological types of BCC. A - Nodular with visible necrotic foci in the neoplastic nodules of BCC. B - Superficial type includes small nodules under the epidermis. C - Micronodular type includes small ovoid or round BCC nodules in the dermis that are limited by palisade basaloid cells in the circumference. D - Infiltrative type: polygonal structures and streaks deeply infiltrating the reticular layer of the dermis. E - Basosquamous (metatypical) type is characterized by infiltrative growth and different sizes of basaloid neoplastic cell clusters intervened with cancerous foci showing signs of abnormal keratosis and dyskeratosis of varying colour. $\mathbf{F}$ - Morpheaform type: small narrow streaks of basaloid cell found between strongly eosinophilic and thickened collagen fibres. This type penetrates deep layers of the dermis and is not qualified for any alternative treatment methods apart from a classic surgical excision with microscopic margin control. G - Nodular pigmented type shows ovoid and round nodules with melanin and dispersed melanophages between the tumour's tissue. $\mathrm{H}$ - Superficial type rich in melanin. I - Nodular BCC creates characteristic empty cracks around nodules after histological processing due to high content of acid mucopolysaccharides

Rycina 4. Typy histologiczne BCC. A - Typ guzkowy (nodular) z widocznymi ogniskami martwicy w środku guzków nowotworowych BCC. B - Typ powierzchowny (superficial) - drobne guzki podwieszające się do naskórka. C - Typ drobnoguzkowy (micronodular) - drobne owalne lub okrągłe guzki BCC w skórze właściwej ograniczające się palisadowymi bazaloidnymi komórkami na obwodzie. D - Typ naciekający (infiltrative) - wielokątne struktury i pasma głęboko naciekające warstwę siateczkowatą skóry właściwej. E - Typ podstawno-kolczystokomórkowy (basosquamous, metatypical) charakteryzuje się naciekającym wzrostem przy różnej wielkości skupiskach bazaloidnych komórek rakowych przeplatających się z ogniskami raka z cechami nieprawidłowego rogowacenia i dyskeratozy o bardziej różowym zabarwieniu. F - Typ twardzinopodobny (morpheaform) - drobne wąskie pasma bazaloidnych komórek układające się między silnie eozynofilnymi i pogrubiałymi włóknami kolagenu. Odmiana ta przenika głębokie warstwy skóry właściwej i nie kwalifikuje się do żadnych alternatywnych metod leczenia poza klasycznym wycięciem chirurgicznym pod mikroskopową kontrolą marginesów. G - Typ guzkowy barwnikowy charakteryzuje się owalnymi i okrągłymi guzkami zawierającymi melaninę oraz rozproszonymi melanofagami między tkanką guza. H - Typ powierzchowny bogaty w melaninę. I - Guzkowy BCC tworzy charakterystyczne puste szczeliny wokół guzków po obróbce histologicznej z powodu dużej zawartości mukopolisacharydów kwaśnych

infiltrative BCC (fig. 4 D), basosquamous (metatypical) BCC (fig. 4 E), and morpheaform BCC (fig. 4 F). Pigmented BCC is a nodular (fig. $4 \mathrm{G}$ ) or superficial (fig. $4 \mathrm{H}$ ) type that includes melanocytes in the tumour tissue and melanophages in the stroma. Histological types describe the nodule size of cancer cells (nodular, micronodular) and their location with regard to the epidermis (superficial, infiltrative) as well as their relationship with stromal cells (infiltrative, morpheaform). BCC nodular foci surround themselves with mucopolysaccharides, which create empty cracks around them after tissue processing (fig. 4 I), whereas infiltrative BCC (fig. 4 D) and all i cech różnicowania komórek guza (BCC adnexogenes), ale charakterystyczne dla nich jest ciemnofioletowe zabarwienie komórek na obwodzie guzka i ich palisadowaty układ (ryc. 4). Najważniejszy podział opiera się jednak na architekturze wzrostu guza BCC, która określa sposób naciekania skóry właściwej. Z biologicznego i rokowniczego punktu widzenia to architektura wzrostu guza warunkuje przebieg kliniczny. W związku z tym opisuje się następujące typy histologiczne BCC: guzkowy (nodular) (ryc. 4 A), powierzchowny (superficial) (ryc. 4 B), drobnoguzkowy (micronodular) (ryc. 4 C) i lejkowo-torbielowaty (infundibulocystic), tworzące grupę o powol- 
the more morpheaform BCC (fig. 4 F) create narrow geometric figures or small streaks tightly adjacent to surrounding collagen fibres. Basal cell carcinoma with aggressive growth leads to deep infiltration of the dermis and requires broad excision margins with clinically unchanged skin performed under the supervision of a microscope. Excision biopsy results should include BCC histological type, lesion size, depth of infiltration, and margin dimensions.

In questionable histological cases, microscopic examination should be supplemented by immunohistochemical staining with Ber-EP4 monoclonal antibody characteristic for BCC that detects a specific epithelial cell adhesion molecule (EpCAM), which is expressed in BCC cells.

\section{HIGH-RISK BASAL CELL CARCINOMA AND RECURRENCE}

Basal cell carcinoma is characterized by a $10 \%$ recurrence risk. The risk increases considerably with usage of inappropriate local therapies and lack of control of margin excisions, especially in cases of aggressively growing BCC types. It amounts to $26 \%$ for infiltrative form as compared with $6 \%$ for nodular form and $3.6 \%$ for superficial form. Anatomical areas, which are burdened with the highest risk of recurrence, include the nose and ear. Most commonly, recurrences appear within 3 years from the day when the primary tumour was removed.

Knowledge of BCC types plays an important role in clinical diagnostics, dermoscopy, as well as interpretation of pathological consultation, and it should exert a significant influence on choosing an appropriate therapeutic method and way of supervising a given patient.

\section{DIAGNOSTICS}

Awareness of typical BCC clinical presentations, locations and history is necessary to make an initial diagnosis. The majority of lesions, up to $80 \%$ of BCC, are found within the skin of head and neck $(90 \%$ of them is found on the face) $[15,16]$. These cancers often coexist with lesions characteristic for excessive exposure to UV radiation, such as lentigines, telangiectasias, or actinic keratosis. In many cases, taking patient's history and macroscopic image of the lesion allow for initial diagnosis of BCC. Dermoscopy is also helpful in diagnosing BCC since it is a specialist and fast non-invasive diagnostic method, which in many atypical clinical presentations may help in deciding about an early initial diagnosis of a cancer [17-19]. Furthermore, it is recommended to use this examination to assess the extent of a neoplastic lesion prior to nej progresji oraz grupę o agresywnym wzroście, do których należą BCC naciekający (infiltrative) (ryc. 4 D), podstawno-kolczystokomórkowy (basosquamous, metatypical) (ryc. 4 E), twardzinopodobny (morpheaform) (ryc. 4 F). Rak podstawnokomórkowy barwnikowy to typ guzkowy (ryc. $4 \mathrm{G}$ ) lub powierzchowny (ryc. $4 \mathrm{H}$ ), zawierający w swoim utkaniu melanocyty, a w podścielisku -melanofagi. Typy histologiczne określają wielkość guzów komórek rakowych (guzkowy, drobnoguzkowy) oraz ich położenie względem naskórka (powierzchowny, naciekający), a także ich stosunek do podścieliska łącznotkankowego (naciekający, twardzinopodobny). Guzkowe ogniska BCC otaczają się mukopolisacharydami, które tworzą wokół nich puste szczeliny po obróbce tkankowej (ryc. 4 I), podczas gdy naciekające BCC (ryc. 4 D), a tym bardziej twardzinopodobne (ryc. 4 F), tworzą wąskie figury geometryczne lub drobne pasma silnie przylegające do otaczających włókien kolagenowych. Raki podstawnokomórkowe o agresywnym wzroście prowadzą do głębokiego naciekania skóry właściwej i wymagają szerokich marginesów klinicznie niezmienionej skóry przy wykonywaniu wycięcia pod kontrolą badania mikroskopowego. Wynik badania materiału pobranego metodą biopsji wycinającej poza typem histologicznym BCC powinien uwzględniać wymiary zmiany, głębokość naciekania i wymiary marginesów.

W wątpliwych histologicznie przypadkach badanie mikroskopowe powinno być uzupełnione o barwienie immunohistochemiczne charakterystyczne dla BCC przeciwciałem monoklonalnym BerEP4, które wykrywa specyficzny antygen adhezyjny komórek nabłonkowych EpCAM (epithelial cell adhesion molecule) ulegający ekspresji w komórkach BCC.

\section{RAK PODSTAWNOKOMÓRKOWY WYSOKIEGO RYZYKA I NAWROTOWOŚĆ}

Rak podstawnokomórkowy skóry charakteryzuje się 10-procentowym ryzykiem wznowy. Ryzyko to wzrasta znacząco po zastosowaniu niewłaściwych terapii miejscowych oraz przy braku kontroli marginesów wycięcia, szczególnie w przypadku agresywnie rosnących odmian BCC. Wynosi ono $26 \%$ dla postaci naciekającej w porównaniu z $6 \%$ dla postaci guzkowej i 3,6\% dla postaci powierzchownej. Okolice anatomiczne, które obciążone są największym ryzykiem wznowy, to nos i ucho. Wznowy najczęściej występują w czasie 3 lat po usunięciu pierwotnego guza.

Znajomość typów BCC odgrywa ważną rolę w diagnostyce klinicznej, dermoskopowej oraz interpretacji oceny histopatologicznej i powinna mieć istotny wpływ na dobór postępowania terapeutycznego oraz monitorowanie pacjenta. 
a planned surgical procedure; in some cases use it as an ex vivo examination of excised foci with appropriate determination for histopathological examination; and as a post-operative scar tissue control tool to diagnose a potential recurrence at an early stage.

Presence of given dermoscopic structures of BCC correlates with a cancer's histopathological sub-type [20-22]. Upon dermoscopy, the presence of palmate/ maple leaf-shaped structures and fine telangiectasias together with simultaneous lack of grey and blue ovoid nests, ulcerations and arborizing vessels suggest a superficial SCC form (algorithm sensitivity amounts to $81.9 \%$, specificity $81.8 \%$ ) (figs. $1 \mathrm{~A}, \mathrm{~B}$ ) [20]. Moreover, confirmation of numerous small erosions or white and pink homogenous areas increase probability of dermoscopic diagnosis of superficial BCC (figs. 1 C, D) [20, 21]. Arborizing vessels constitute the most characteristic dermoscopic feature in nodular BCC (figs. 2 A, B) [21], with additional accompanying grey and blue ovoid nests in pigmented BCC (figs. 2 C, D) [21]. The infiltrative type is characterized by the presence of diffused fine telangiectasias that show a tendency to create smaller branches localized on the yellow and red background (figs. 3 A, B) [22]. Upon dermoscopy, the morpheaform type is characterized by white background with single arborizing vessels and numerous brown granules (figs. 3 C, D) [22]. Basosquamous cell carcinoma shows features suggestive of both BCC (grey and blue ovoid nests, ulcerations, grey and blue areas) and SCC (hyperkeratosis, white homogenous areas, spoke-wheel patterns, keratin masses with ecchymoses) in dermoscopy (figs. 3 E, F) [22, 23]. Polarized light dermoscopy in cases of non-pigmented BCC reveals also presence of glittering white lamellae and streaks occurring in the superficial (figs. $1 \mathrm{C}, \mathrm{D})$, nodular (figs. $2 \mathrm{~A}, \mathrm{~B}$ ), and morpheaform types of BCC [24]. Determining a histopathological type conditions the choice of a treatment method. Dermoscopic confirmation of presence of pigmented structures characteristic for BCC foci, which are clinically defined as pigmented (figs. 2 C, D) but occur in non-pigmented lesions, may suggest a low response to treatment methods other than surgical excision of the above-mentioned lesion [25].

In diagnostically difficult BCC cases, especially the ones in the form of small-dimension foci, reflectance confocal microscopy (RCM) may be used since it shows presence of structures typical for BCC [26].

Optical coherence tomography (OCT) or skin ultrasound may be helpful in pre-operative assessment of neoplastic boarders. Histopathological examination remains a gold standard in diagnosis BCC.

Determining cancer's histopathological type, level of lesion progress, and assessment of patient's general condition are of key importance in selecting

\section{DIAGNOSTYKA}

Znajomość charakterystycznych dla BCC obrazów klinicznych, lokalizacji oraz wywiadu jest niezbędna do ustalenia wstępnego rozpoznania. Większość zmian, bo aż 80\% BCC, zlokalizowana jest w obrębie skóry głowy i szyi (z czego 90\% na twarzy) [15, 16]. Często raki te współistnieją ze zmianami charakterystycznymi dla nadmiernej ekspozycji na promieniowanie UV, takimi jak liczne plamy soczewicowate, teleangiektazje i rogowacenie słoneczne. W wielu przypadkach typowy wywiad oraz wygląd makroskopowy zmiany umożliwia prawidłowe ustalenie wstępnego rozpoznania BCC. W diagnostyce BCC pomocna jest również dermoskopia - specjalistyczna i szybka, nieinwazyjna metoda diagnostyczna, która $\mathrm{w}$ wielu nietypowych obrazach klinicznych może rozstrzygać o wczesnym, wstępnym rozpoznaniu nowotworu [17-19]. Zaleca się ponadto zastosowanie tego badania do oceny rozległości zmiany nowotworowej przed planowanym zabiegiem chirurgicznym, w wybranych przypadkach jako badania ex vivo wyciętych ognisk z odpowiednim oznaczeniem do badania histopatologicznego oraz pooperacyjnej kontroli blizny w celu wczesnego wykrycia potencjalnej wznowy.

Występowanie określonych struktur dermoskopowych BCC koreluje z podtypem histopatologicznym nowotworu [20-22]. Obecność w dermoskopii struktur palczastych lub przypominających liście klonu oraz cienkich teleangiektazji z jednoczesnym brakiem szaroniebieskich gniazd owalnych, owrzodzenia oraz naczyń drzewkowatych sugeruje postać powierzchowną BCC (czułość algorytmu wynosi 81,9\%, swoistość $81,8 \%$ ) (ryc. 1 A, B) [20]. Ponadto stwierdzenie licznych, drobnych nadżerek oraz białoróżowych obszarów homogennych zwiększa prawdopodobieństwo dermoskopowego rozpoznania powierzchownej postaci BCC (ryc. 1 C, D) [20, 21]. Naczynia drzewkowate stanowią najbardziej charakterystyczną cechę dermoskopową odmiany guzkowej BCC (ryc. 2 A, B) [21], z dodatkowo towarzyszącymi strukturami szaroniebieskich gniazd owalnych w jego odmianie barwnikowej (ryc. 2 C, D) [21]. Postać naciekająca charakteryzuje się rozproszonymi, cienkimi teleangiektazjami wykazującymi tendencję do tworzenia mniejszych rozgałęzień zlokalizowanych na żółto-czerwonym podłożu (ryc. 3 A, B) [22]. Postać twardzinopodobna cechuje się $\mathrm{w}$ dermoskopii białym podłożem z pojedynczymi cienkimi naczyniami drzewkowatymi oraz licznymi brązowymi ziarnistościami (ryc. 3 C, D) [22]. Rak podstawnokolczystokomórkowy skóry ma cechy sugerujące $\mathrm{w}$ dermoskopii zarówno BCC (szaroniebieskie gniazda owalne, owrzodzenie, szaroniebieskie obszary), jak i SCC (hiperkeratoza, białe homogenne obszary, objaw białych kół, masy keratynowe z wybroczynami) (ryc. 3 E, F) [22, 23]. Badanie dermoskopowe ze 
the right treatment method. When there exists a suspicion that the neoplasm may infiltrate deeper tissues, it is recommended to broaden the diagnostics with imaging examinations. When involvement of lymph nodes is suspected, it is necessary to perform a fine-needle aspiration biopsy or remove an entire lymph node to assess it microscopically $[2,3]$.

\section{CLINICAL STAGES}

In order to determine a clinical stage of skin cancer, a classification prepared by American Joint Committee on Cancer (AJCC, revised in 2009 and 2017) is used that is based on standard evaluation of TNM traits ( $\mathrm{T}$ - tumour, $\mathrm{N}$ - node, $\mathrm{M}$ - metastasis). Due to the fact that basal cell carcinoma metastases to regional lymph nodes and distant organs are infrequent, this classification is rarely used, and therefore, it is not included in this paper. A more clinically important method of stratification of patients with diagnosed locally advanced BCC is determination of the cancer recurrence risk. In such cases the preferred method of risk assessment is the one proposed by National Comprehensive Cancer Network (NCCN, version 1, 2018) [3]. It includes both clinical and pathological parameters (table 1) that allow for qualifying a lesion into a high recurrence risk group or a low recurrence risk group.

\section{TREATMENT METHODS}

The superior aim of therapies in cases of skin cancers is a complete removal of neoplastic tissue, what will limit the risk of failure for local treatment, while

Table I. Risk assessment for basal cell carcinoma according to National Comprehensive Cancer Network

\begin{tabular}{lcc} 
Location and size & Low risk & High risk \\
& Area $\mathrm{L}<20 \mathrm{~mm}$ & Area $\mathrm{L} \geq 20 \mathrm{~mm}$ \\
\hline & Area $\mathrm{M}<10 \mathrm{~mm}$ & Area $\mathrm{M} \geq 10 \mathrm{~mm}$ \\
\hline Boarders & Well defined & Prea $\mathrm{H}$ \\
\hline Primary vs. recurrent & Primary & Recurrent \\
\hline Immunosuppression & No & Yes \\
\hline Prior RT & No & Yes \\
\hline Pathology: subtype & Nodular, & Aggressive growth \\
& superficial & pattern \\
\hline Perineural involvement & No & Yes
\end{tabular}

Area $L$ - trunk and extremities, excluding pretibial, hands, feet, ankles, and nail units; area $M$ - central face, cheeks, forehead, scalp, neck, and pretibial; area $\mathrm{H}$ - head and neck excluding area $\mathrm{M}$, genitals, hands and feet. światłem spolaryzowanym, przede wszystkim w bezbarwnikowych postaciach BCC, uwidacznia ponadto obecność lśniących białych blaszek oraz pasm, występujących w odmianie powierzchownej (ryc. 1 C, D), guzkowej (ryc. 2 A, B) i twardzinopodobnej BCC [24]. Określenie podtypu histopatologicznego warunkuje wybór metody leczenia. Dermoskopowe stwierdzenie struktur barwnikowych charakterystycznych dla ognisk BCC klinicznie definiowanych jako barwnikowe (ryc. 2 C, D), ale również występujące w zmianach bezbarwnikowych, może świadczyć o niskiej odpowiedzi powyższej zmiany na inne metody leczenia niż wycięcie chirurgiczne [25].

W trudnych diagnostycznie przypadkach BCC, szczególnie mających postać ognisk o małej średnicy, można wykonać refleksyjną mikroskopię konfokalną (reflectance confocal microscopy - RCM), która wykazuje obecność struktur charakterystycznych dla BCC [26].

Optyczna tomografia koherencyjna lub badanie ultrasonograficzne skóry są pomocne w przedoperacyjnej ocenie granic nowotworu. Badanie histopatologiczne jest złotym standardem rozpoznawania BCC.

Ustalenie typu histopatologicznego nowotworu, określenie stopnia zaawansowania zmiany oraz ocena stanu ogólnego pacjenta mają decydujące znaczenie w wyborze odpowiedniej metody leczenia. W przypadku podejrzenia naciekania przez nowotwór głębiej położonych tkanek wskazane jest poszerzenie diagnostyki o badania obrazowe. $W$ razie podejrzenia zajęcia węzłów chłonnych niezbędne jest wykonanie biopsji aspiracyjnej cienkoigłowej lub pobranie całego węzła w celu oceny mikroskopowej $[2,3]$.

Tabela I. Ocena ryzyka dla raka podstawnokomórkowego według National Comprehensive Cancer Network

\begin{tabular}{lcc} 
Lokalizacja i rozmiar & $\begin{array}{c}\text { Zmiana niskiego } \\
\text { ryzyka }\end{array}$ & $\begin{array}{c}\text { Zmiana wysokiego } \\
\text { ryzyka }\end{array}$ \\
& Obszar $\mathrm{L}<20 \mathrm{~mm}$ Obszar $\mathrm{L} \geq 20 \mathrm{~mm}$ \\
\hline & \multicolumn{2}{c}{ Obszar $\mathrm{M}<10 \mathrm{~mm}$ Obszar $\mathrm{M} \geq 10 \mathrm{~mm}$} \\
\hline Brzegi zmiany & $\begin{array}{l}\text { Dobrze, ostro } \\
\text { odgraniczone }\end{array}$ & Granice nieostre \\
\hline $\begin{array}{l}\text { Guz pierwotny lub } \\
\text { nawrotowy }\end{array}$ & Pierwotny & Nawrotowy \\
\hline Immunosupresja & Nie & Tak \\
\hline $\begin{array}{l}\text { Wcześniejsza } \\
\text { radioterapia }\end{array}$ & Nie & Tak \\
\hline $\begin{array}{l}\text { Typ histopatologiczny } \\
\text { Guzkowy, }\end{array}$ & Naciekający \\
\hline $\begin{array}{l}\text { Naciekanie } \\
\text { okołonerwowe }\end{array}$ & Nie & Tak \\
\hline
\end{tabular}

Obszar L - tułów i kończyny z wyłaczeniem wyprostnej powierzchni podudzia, rąk, stóp, kostek i paznokci; obszar M - część środkowa twarzy, policzki, czoło, skóra owtosiona głowy, szyja, myprostna powierzchnia podudzia; obszar H - głowa i szyja z wyłączeniem obszaru M, genitalia, ręce i stopy. 
simultaneous consideration for the best cosmetic result of the procedure.

When selecting the best BCC treatment method, the following should also be taken into account:

- number and size of lesions,

- histopathological type,

- possibility to preserve organ functions, and achieve aesthetic results,

- efficacy of the therapy,

- treatment tolerance (pain, treatment time, adverse reactions, risk for complications),

- availability of a given therapeutic method,

- immunological condition of a given patient,

- patient's preferences and expectations.

Available skin cancer treatment methods include:

1) surgical treatment:

- allowing for assessing treatment margins (first choice therapies):

- classic radical excision of the lesion,

- Mohs micrographic surgery;

- no possibility to assess treatment margins:

- cryosurgery,

- electrotherapy,

- laser therapy;

2) non-surgical treatment:

- radiation therapy,

- superficial with the use of:

- 5-fluorouracil,

- imiquimod,

- photodynamic therapy;

3) general treatment:

- vismodegib,

- sonidegib.

A scheme of a proposed therapeutic procedure in cases of a suspected basal cell skin carcinoma is presented in figure 5 .

\section{Surgical methods}

Recommendations of all international societies are consistent - surgery invariably remains a "gold standard" in BCC treatment (except for non-operative lesions) regardless of the possible recurrence risk. Often, this method is the fastest and the most efficient procedure allowing for performing complete histopathological diagnostics of the removed lesion. In case of BCC with low risk of recurrence, it is recommended to perform a standard excision with a $4 \mathrm{~mm}$ margin of healthy tissues. In cases of possible cosmetic defects it is possible to make the excision with a smaller margin provided that it is free from neoplastic cells (R0).

With low recurrence risk cancers it is recommended, if possible, to perform an intra-operative analysis whether the procedure has been radical or not. Treatment of skin basal cell carcinomas by means of Mohs micrographic surgery (MMS), i.e. a method based on

\section{STOPNIE ZAAWANSOWANIA KLINICZNEGO}

Do oceny stopnia zaawansowania raków skóry stosuje się klasyfikację opracowaną przez Amerykańskie Towarzystwo do Walki z Rakiem (American Joint Committee on Cancer - AJCC, aktualizacja z roku 2009 oraz 2017), która opiera się na standardowej ocenie cech TNM [T - tumour (guz), N - node (węzeł), M - metastasis (przerzut)]. Ze względu na niewielką częstość występowania przerzutów BCC do regionalnych węzłów chłonnych i narządów odległych klasyfikacja ta jest rzadko używana, dlatego nie została ujęta w tym opracowaniu. Bardziej istotną klinicznie metodą stratyfikacji pacjentów z rozpoznaniem miejscowo zaawansowanych postaci BCC jest określenie ryzyka nawrotu nowotworu. W tych przypadkach preferuje się metodę oceny ryzyka zaproponowaną przez National Comprehensive Cancer Network (NCCN, wersja 1 z 2018 roku) [3]. Uwzględniono w niej zarówno parametry kliniczne, jak i patologiczne (tab. 1), które umożliwiają zakwalifikowanie zmiany do grupy wysokiego lub niskiego ryzyka nawrotu.

\section{METODY LECZENIA}

Nadrzędnym celem postępowania terapeutycznego w przypadku raków skóry jest doszczętne usunięcie tkanek nowotworowych, co ogranicza ryzyko niepowodzenia leczenia miejscowego, $\mathrm{z}$ jednoczesnym uzyskaniem jak najlepszego efektu kosmetycznego zabiegu.

Przy wyborze najbardziej odpowiedniej metody leczenia BCC należy uwzględnić także:

- liczbę i rozmiary zmian,

- typ histopatologiczny,

- możliwość zachowania funkcji narządu oraz uzyskany efekt estetyczny,

- skuteczność terapii,

- tolerancję leczenia (dolegliwości bólowe, czas leczenia, działania niepożądane, ryzyko wystąpienia powikłań),

- dostępność danej metody terapeutycznej,

- stan odporności immunologicznej pacjenta,

- preferencje i oczekiwania pacjenta.

Wśród dostępnych metod terapii raków skóry wyróżnia się:

1) leczenie zabiegowe:

- umożliwiające ocenę marginesów (terapie pierwszego wyboru):

- klasyczne radykalne wycięcie zmiany, - chirurgia mikrograficzna metodą Mohsa;

- bez możliwości oceny marginesów:

- kriochirurgia,

- elektroterapia,

- laseroterapia;

2) leczenie niezabiegowe:

- radioterapia,

- powierzchowne, z zastosowaniem: 


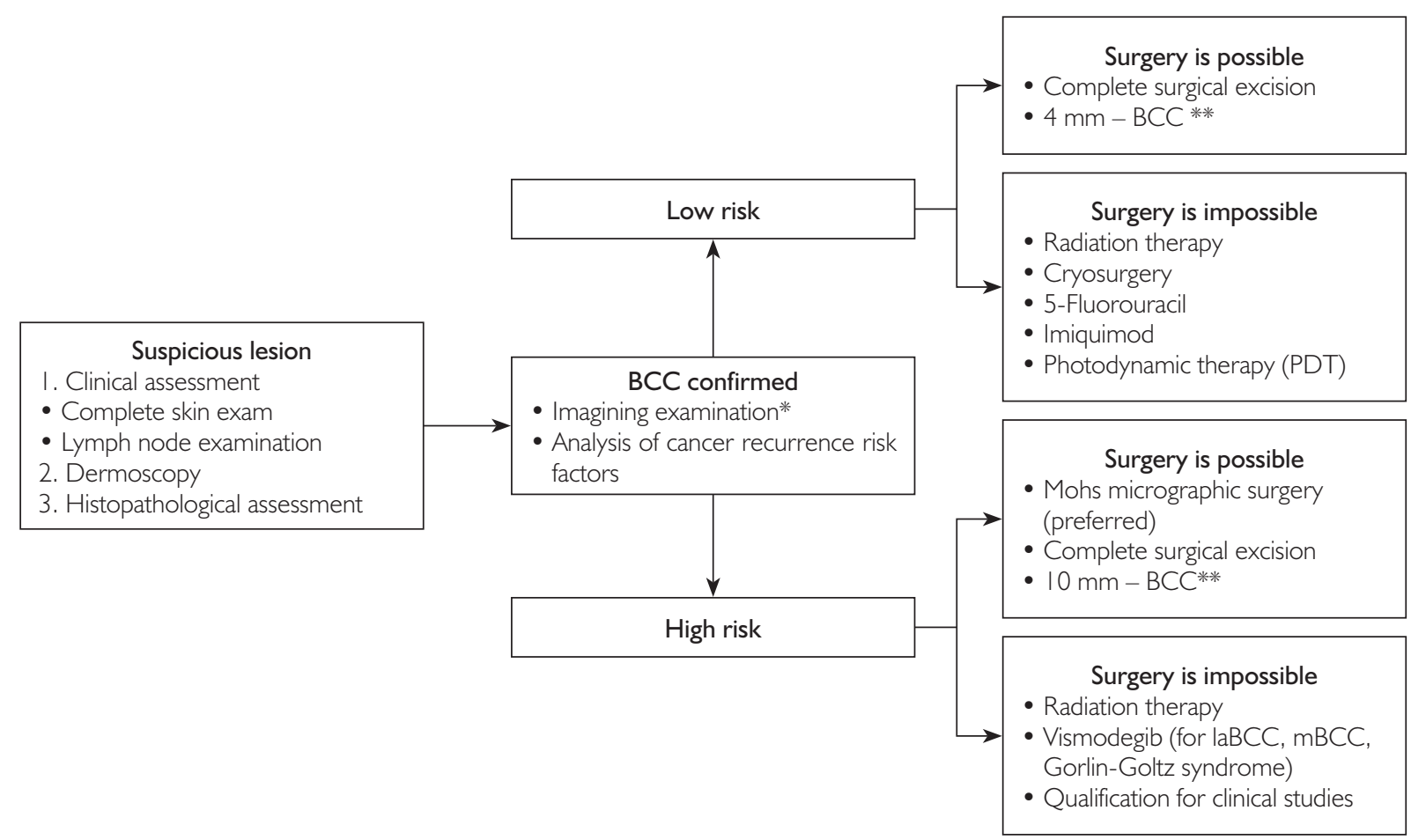

Figure 5. A scheme of a proposed therapeutic procedure in cases of skin cancer

*In cases of a suspected advanced lesion or infiltration into soft tissues, bones, vessels, etc. (MRI or CT). **In cases of possible considerable cosmetic defects, excision with a smaller margin is possible, however, it must be (ultimately) free from neoplastic cells (RO). laBCC - locally advanced BCC; mBCC - metastatic $B C C$

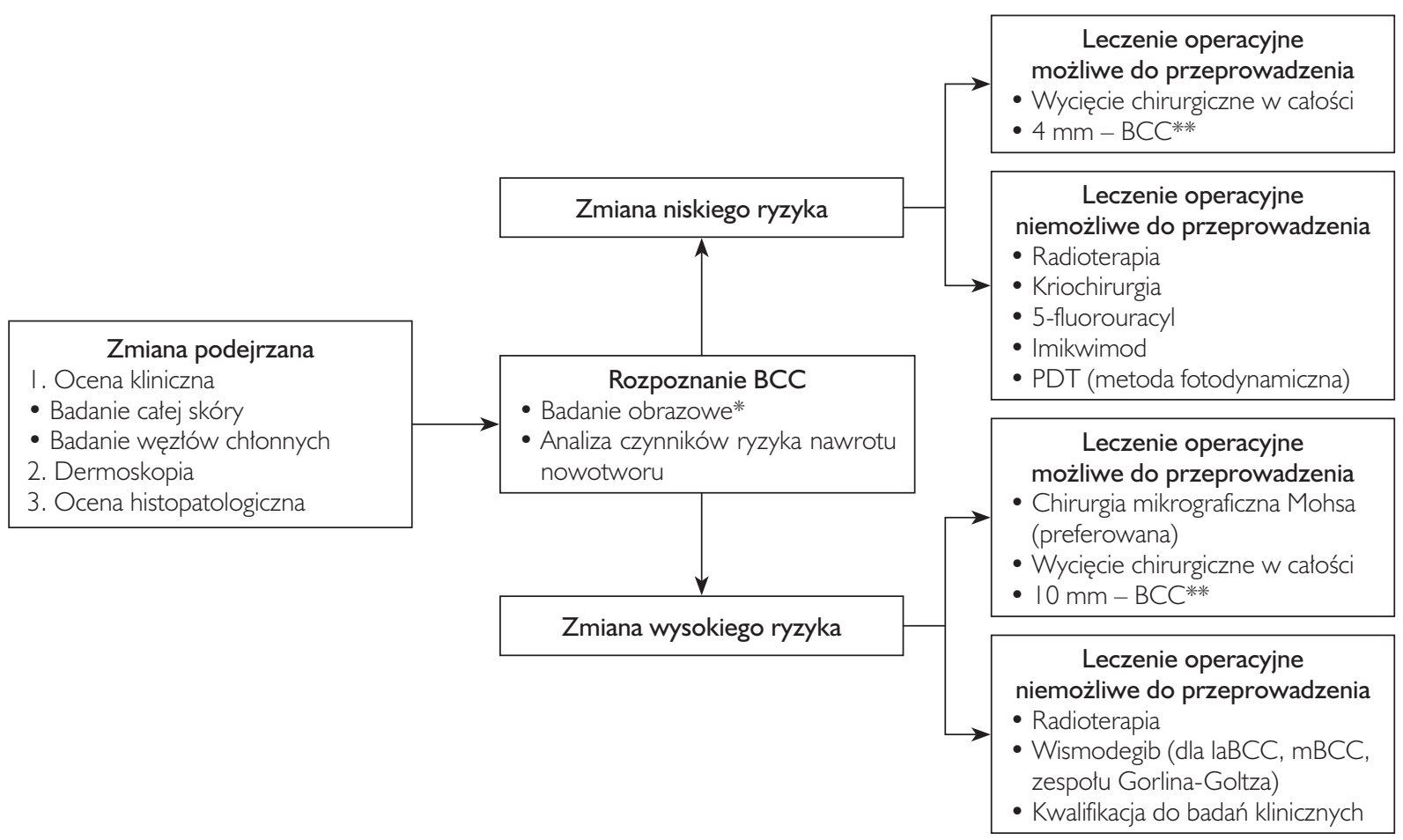

Rycina 5. Schemat proponowanego postępowania terapeutycznego w przypadku raka skóry

*W przypadku podejrzenia zmiany zaawansowanej lub nacieku na tkanki miękkie, kości, naczynia itd. (MRI lub CT). **W przypadku znaczq̨cych ubytków kosmetycznych wycięcie z mniejszym marginesem jest możliwe, jednak musi ono być (docelowo) wolne od komórek nowotworowych (RO). laBCC - miejscowo zaawansowany BCC, $\mathrm{mBCC}-$ przerzutowy BCC. 
staged surgical excision of the tumour with a subsequent intra-operative histological assessment of margins with regard to radicalness (subsequently excised sections from the tumour bed's margin are assessed with regard to tumour presence), becomes more and more common in Poland. This method provides the highest treatment rates and ensures maximal preservation of healthy tissues, what allows for keeping aesthetic appearance of patients' skin. In cases when it is impossible to excise a lesion with high recurrence risk by means of MMS, it is recommended to apply wider $10 \mathrm{~mm}$ excision margins.

\section{Cryosurgery}

Cryosurgery is an ablation technique based on using a liquid nitrogen or nitrous oxide for induction of neoplastic cells' thermic necrosis by creating a low temperature at the basis of tumour's tissue, within the range from -50 to $-60^{\circ} \mathrm{C}$. This method applies to treatment of superficial BCC with low recurrence risk and size up to $2 \mathrm{~cm}$. In order to ensure the highest radicalness possible, neoplastic tissue together with a healthy skin margin should be destroyed. Wounds heal usually well after the treatment, and there appear small cosmetic scars [3].

Due to the lack of sufficient data regarding efficacy of laser therapy, this method is not recommenced in treatment of skin cancers.

\section{Radiation therapy}

Radiation therapy (RT) is an alternative treatment for patients, who do not qualify for surgeries or do not give their consent to perform such a procedure. Results of a remote BCC treatment with the use of radiation therapy are very good. Analysis of retrospective studies of BCC patients treated with RT show a percentage of 5-year treated cases from 93\% to $96 \%$ $[3,27-30]$, and the risk of 5-year recurrences from $4 \%$ to $16 \%$ [3, 27-29]. Radiation therapy shows a slightly higher efficacy in cases of primary BCC rather than recurrent; moreover, it shows a higher efficacy in cases of lesions with a smaller diameter and nodular subtype $[3,27,28,30]$.

Radiation therapy is also important as a method of supplemental therapy in patients after a non-radical excision or a cytoreductive surgery, in whom the procedure has been incomplete due to neoplastic infiltration of important structures, and also after a lymphadenectomy due to metastases to regional lymph nodes.

\section{Superficial methods}

Surgery is the most effective treatment method for BCC lesions. However, in cases when this method cannot be used, other therapeutic methods includ-
- 5-fluorouracylu,

- imikwimodu,

- terapii fotodynamicznej;

3) leczenie ogólne:

- wismodegib,

- sonidegib.

Schemat proponowanego postępowania terapeutycznego w przypadku podejrzenia BCC przedstawiono na rycinie 5.

\section{Metody chirurgiczne}

Zalecenia wszystkich światowych towarzystw są zgodne - chirurgia jest niezmiennie złotym standardem leczenia BCC (z wyjątkiem zmian nieoperacyjnych), niezależnie od ryzyka ewentualnego nawrotu. Metoda ta jest często najszybszym i najskuteczniejszym postępowaniem, które umożliwia dokonanie pełnej diagnostyki histopatologicznej usuniętej zmiany. W przypadku BCC o niskim ryzyku nawrotu zaleca się wykonanie standardowego wycięcia z zachowaniem 4-milimetrowego marginesu zdrowych tkanek. W przypadku możliwych ubytków kosmetycznych wykonuje się wycięcie z mniejszym marginesem, pod warunkiem że jest on wolny od komórek nowotworowych (R0).

W przypadku raka o wysokim ryzyku nawrotu zaleca się, jeśli jest to możliwe, śródoperacyjną analizę doszczętności zabiegu. Leczenie BCC z zastosowaniem mikrochirurgii Mohsa (Mohs micrographic surgery - MMS), czyli metody polegającej na etapowym chirurgicznym wycięciu nowotworu z następczą śródoperacyjną histologiczną oceną marginesów pod kątem radykalności (docinane fragmenty z brzegów loży guza są oceniane pod kątem obecności komórek guza), jest coraz bardziej powszechne w Polsce. Metoda ta zapewnia najwyższe wskaźniki wyleczalności przy jednocześnie największym możliwym zaoszczędzeniu zdrowych tkanek, przez co pozwala zachować walory estetyczne skóry pacjentów. Gdy nie można wyciąć zmiany o wysokim ryzyku nawrotu przy użyciu MMS, rekomenduje się zastosowanie szerszych, 10-milimetrowych marginesów.

\section{Kriochirurgia}

Kriochirurgia jest techniką ablacyjną polegającą na zastosowaniu płynnego azotu lub podtlenku azotu do indukcji martwicy termicznej komórek nowotworowych poprzez wytworzenie niskiej temperatury u podstawy tkanki guza, w zakresie od $-50^{\circ} \mathrm{C}$ do $-60^{\circ} \mathrm{C}$. Metoda ta ma zastosowanie w leczeniu powierzchownych typów BCC o niskim ryzyku nawrotu i rozmiarach do $2 \mathrm{~cm}$. W celu zapewnienia jak największej radykalności zabiegu zniszczona powinna zostać tkanka nowotworowa wraz z marginesem zdrowej skóry. Gojenie ran po zabiegu zazwyczaj przebiega prawidłowo, z tworzeniem niewielkich, kosmetycznych blizn [3]. 
ing the following should be considered: local therapy (imiquimod or 5-fluoroacyl), or a photodynamic therapy with aminolevulinic acid (ALA) or methyl aminolevulinate (MAL). Yet, it should be remembered that these methods show a considerably lower treatment rates than surgeries, and thus, they should be considered only in cases of cancers with low recurrence risk, non-aggressive growth pattern that is confirmed histologically in patients with small tumours, who cannot use radical treatment methods due to various reasons [2, 3]. Furthermore, one should keep in mind that BCC in patients under $35 \mathrm{y} / \mathrm{o}$ often has an aggressive clinical course and regardless of patient's preferences and aesthetics, surgical excision should be considered and performed in the first place as the recurrence risk is high.

\section{Imiquimod (5\%)}

Imiquimod is a local modifier of immunological response, whose anti-neoplastic activity is used in treatment of superficial BCC. A cream preparation is used for 6 weeks, 5 times a week, once a day in the evening, preferably for 8 hours. As it has been indicated in a prospective study in patients with superficial BCC, disease recurrence was not observed within 5 years in $85 \%$ of patients treated with imiquimod.

Adverse reaction associates with local imiquimod treatment include skin redness, oedema, formation of vesicles, pruritus, and sometimes tingling sensation [31].

\section{5-Fluorouracil (0.5\%)}

Another local cream preparation used in therapies of superficial BCC is 5-fluorouracil (5-FU). In a randomized study, this preparation showed similar results in terms of efficacy, safety, and a similar cosmetic effect as imiquimod [2,32]. Typical schemes recommend using it twice a day for at least 3-6 weeks, although in some cases it may be necessary to use it for 10-12 weeks.

\section{Photodynamic therapy}

Photodynamic therapy (PDT) is used in superficial and nodular BCC after a prior curetting of the latter type. This method is based on using light (emitted from SoLux light bulbs, LEDs, or lasers) to activate a photosensitizer applied on affected tissues, what prompts a creation of cytotoxic reactive singlet forms of oxygen [32]. In this method, a $\delta$-aminolevulinic acid (ALA) or its methyl derivative - methyl aminolevulinate (MAL) - are used. Data obtained from analyses of clinical studies show that a percentage of BCC patients treated with PDT amount to 70-90\% [3, 33, 34]; a higher frequency of treatment is observed in cases of superficial BCC rather than in nodular BCC
Ze względu na brak wystarczających danych dotyczących skuteczności laseroterapii metoda ta nie jest zalecana w leczeniu raków skóry.

\section{Radioterapia}

Radioterapia (RT) stanowi alternatywę dla pacjentów, którzy nie kwalifikują się do leczenia operacyjnego lub też nie wyrażają na nie zgody. Wyniki odległego leczenia BCC z zastosowaniem radioterapii są bardzo dobre. $W$ analizie badań retrospektywnych pacjentów z BCC leczonych RT odsetek 5-letnich wyleczeń wynosi 93-96\% [3, 27-30], a ryzyko 5-letnich nawrotów - 4-16\% [3, 27-29]. Radioterapia cechuje się nieco wyższą skutecznością w przypadku pierwotnych BCC niż nawrotowych, a także wyższą skutecznością w przypadku zmian o mniejszej średnicy i podtypie guzkowym [3, 27, 28, 30].

Radioterapia ma również duże znaczenie jako metoda terapii uzupełniającej u pacjentów po nieradykalnym usunięciu lub po cytoredukcji guza, u których wykonany zabieg jest niekompletny ze względu na naciekanie przez nowotwór ważnych struktur, a także po limfadenektomii z powodu przerzutów do regionalnych węzłów chłonnych.

\section{Metody powierzchowne}

Chirurgia jest najbardziej skuteczną metodą leczenia zmian typu BCC. Jednak w sytuacjach, gdy metoda ta nie może być zastosowana, należy rozważyć wykorzystanie innych terapii, takich jak leczenie miejscowe (imikwimod lub 5-fluorouracyl), terapia fotodynamiczna z zastosowaniem kwasu aminolewulinowego (ALA) lub aminolewulinianu metylu (MAL). Należy jednak pamiętać, że metody te charakteryzują się zdecydowanie niższym wskaźnikiem wyleczeń niż metody operacyjne, dlatego powinny być rozważane wyłącznie w przypadku nowotworów o niskim ryzyku nawrotu, nieagresywnym typie wzrostu potwierdzonym histologicznie, u chorych z niewielkimi guzami, którzy z różnych przyczyn nie mogą skorzystać z bardziej radykalnych terapii $[2,3]$. Warto także pamiętać, że BCC występujące poniżej 35. roku życia mają często agresywny przebieg kliniczny i niezależnie od preferencji pacjenta i argumentów estetycznych na pierwszym miejscu powinno się rozważać i stosować wycięcie chirurgiczne z powodu dużego ryzyka wznowy.

Imikwimod (5\%)

Imikwimod jest miejscowym modulatorem odpowiedzi immunologicznej, którego działanie przeciwnowotworowe wykorzystywane jest w leczeniu powierzchownego BCC. Preparat w formie kremu stosuje się przez 6 tygodni, 5 razy w tygodniu, raz dziennie - wieczorem, najlepiej na 8 godzin. Jak wy- 
$[3,35]$. Furthermore, a considerable thickness of the lesions and presence of ulceration may exert a negative influence on PDT effects [3, 35]. A metanalysis of 23 randomized and non-randomized studies from 2012 did not show a significant difference in PDT efficacy as compared with imiquimod in therapies of superficial BCC $[3,36]$. In a randomized study conducted in 2013 treatment effects of over 600 patients with this type of basal cell carcinoma were assessed. Remission of neoplastic lesions was confirmed in 73\% of patients treated with MAL-PDT (2 sessions with a one week break) as compared with $83 \%$ of patients treated with imiquimod (5 times a week for 6 weeks), and $80 \%$ of patients treated with 5 -FU (twice a day for 4 weeks). An analysis of sub-groups revealed that treatment efficacy indicators were significantly higher in case of imiquimod as compared with PDT in cases of tumour with bigger dimensions, localized on the trunk; PDT achieves much better results than imiquimod in elderly patients with smaller lesions found on lower extremities [3, 37].

\section{General treatment}

Registering vismodegib - the first micromolecular hedgehog pathway inhibitor - in Europe and the USA was a quantum leap in therapy of patients with locally advanced BCC (laBCC) and metastatic BCC $(\mathrm{mBCC})$, in whom surgical treatments and radiation therapy have been exhausted or there is no possibility to use the aforementioned, and in patients with genetically conditioned Gorlin-Goltz syndrome [3]. Vismodegib is an oral drug in a standard dose of $150 \mathrm{mg}$ / day till the moment of progression or toxicity making the treatment continuation impossible.

In ERIVANCE clinical study, which constituted the basis for registration of vismodegib, median for progression-free survival (PFS) in a group of $\mathrm{mBCC}$ patients amounted to 9.3 months, whereas, in a group of laBCC patients (non-operative, not qualifying for radiation therapy) it amounted to 12.9 months; median for time to treatment response was 14.8 and 26.2 months accordingly. Objective response (OR) among laBCC patients $(47.6 \%)$ was slightly higher than in the case of mBCC (33.3\%) [38].

In patients with Gorlin-Goltz syndrome, the drug considerably limited appearance of new BCC in the group that was given vismodegib as compared with placebo. In none of the patients who were administered the drug BCC progression was observed; in some patients even a complete clinical remission of neoplastic lesions occurred [39]. The most popular adverse reactions of a vismodegib therapy include: muscle contractions, taste disorders, alopecia, body weight loss, nausea, and diarrhoea [3, 38, 39].

In Poland since January 2017 vismodegib is an available therapeutic option within Drug Prescription kazano w prospektywnym badaniu przeprowadzonym u pacjentów z powierzchowną postacią BCC, u $85 \%$ pacjentów leczonych imikwimodem nie zaobserwowano nawrotów choroby w czasie 5 lat $[3,31]$.

Działania niepożądane związane z miejscowym leczeniem imikwimodem obejmują: zaczerwienienie skóry, obrzęk, tworzenie się pęcherzyków, świąd i czasami uczucie mrowienia [31].

\section{5-Fluorouracyl $(0,5 \%)$}

Innym preparatem miejscowym w kremie stosowanym w terapii powierzchownego BCC jest 5-fluorouracyl (5-FU). W badaniu z randomizacją uzyskał on podobne wyniki skuteczności i bezpieczeństwa oraz zbliżony efekt kosmetyczny jak imikwimod [2, 32]. Typowe schematy zalecają stosowanie 2 razy dziennie przez przynajmniej 3-6 tygodni, choć w niektórych przypadkach konieczne może być stosowanie przez 10-12 tygodni.

\section{Terapia fotodynamiczna}

Terapia fotodynamiczna (photodynamic therapy - PDT) stosowana jest w powierzchownych BCC, a także w guzkowych po wcześniejszym wyłyżeczkowaniu. Metoda ta polega na użyciu światła (emitowanego z żarówek soluksowych, LED lub laserów) do aktywacji fotouczulacza aplikowanego na zmienione chorobowo tkanki, co powoduje tworzenie cytotoksycznych, reaktywnych, singletowych form tlenu [32]. W metodzie tej jako fotouczulacz stosuje się kwas $\delta$-aminolewulinowy (ALA) lub jego metylową pochodną - aminolewulinian metylu (MAL). Dane uzyskane na podstawie analiz badań klinicznych wykazują, że odsetek wyleczeń pacjentów z rozpoznaniem BCC przy użyciu PDT wynosi od 70\% do $90 \%$ [3, 33, 34], przy czym wyższą częstość wyleczeń obserwuje się w przypadku powierzchownych typów BCC niż guzkowych [3, 35]. Duża grubość zmiany oraz obecność owrzodzenia również negatywnie wpływają na efekty terapii fotodynamicznej [3, 35]. Metaanaliza 23 badań z randomizacją i bez randomizacji z 2012 roku nie wykazała istotnej różnicy w skuteczności PDT w porównaniu z imikwimodem w terapii powierzchownych BCC $[3,36]$. W przeprowadzonym w 2013 roku badaniu z randomizacją oceniano efekty leczenia ponad 600 pacjentów $\mathrm{z}$ tą postacią BCC. Remisję zmian nowotworowych stwierdzono u 73\% leczonych MAL-PDT (2 sesje w odstępie tygodnia) w porównaniu z $83 \%$ pacjentów leczonych imikwimodem (5 razy w tygodniu przez 6 tygodni) oraz $80 \%$ pacjentów leczonych 5-FU (2 razy dziennie przez 4 tygodnie). Analiza podgrup wykazała, że wskaźniki skuteczności leczenia były istotnie większe dla imikwimodu w porównaniu z PDT w przypadku guzów o dużych wymiarach, zlokalizowanych na tułowiu, podczas gdy PDT za- 
Program of Polish National Health Fund for patients with metastatic or locally advanced basal cell carcinoma, which does not meet the criteria for surgical treatment or radiation therapy. Another micromolecular hedgehog pathway inhibitor, which is registered in the USA, is sonidegib.

New perspectives

Currently, there is a study conducted that assesses application of vismodegib in neoadjuvant therapies in patients with locally advanced BCC (VISMONEO study), and also looks into ways of how to overcome resistance mechanisms of therapies including hedgehog pathway inhibitors [40].

Initial results indicate that pre-operative usage of vismodegib allows for decreasing the size of a tumour, what in special cases makes it possible to conduct a surgery in locally advanced BCC [40].

\section{OBSERVATION AFTER TERMINATED ONCOLOGICAL TREATMENT}

In case of patients, in whom BCC developed, it is recommended to provide a long-term observation after the treatment has been terminated. It regards especially those patients, who are at high risk of cancer recurrence. Moreover, education of patients with emphasis placed on protection against the sun (SPF 30-50+ preparations) and importance of secondary prophylaxis, including regular self-control of the skin at least once a month, plays a significant role in care over the BCC patients after the termination of oncological therapy [4].

Period encompassing the first 2 years of observation is the most critical; therefore, patients should undergo regular dermatological examinations with dermoscopy within that time (table 2).

\section{CONCLUSIONS}

It should be remembered that in all cases diagnostic and therapeutic decisions are made by a physician, co-operating with a given patient, that is governed by contemporary medical knowledge and potential efficacy as well as safety profile, which justify the choice of a specific treatment option in the specific clinical situation. Treatment methods presented in this paper are mere general advice. The paper does not constitute recommendations of Polish Dermatological Society with regard to any specific medicinal products, medicinal devices or manufacturers.

\section{CONFLICT OF INTEREST}

The authors declare no conflict of interest. pewnia znacznie lepsze wyniki niż imikwimod u pacjentów w podeszłym wieku z mniejszymi zmianami zlokalizowanymi na kończynach dolnych [3, 37].

\section{Leczenie ogólne}

Zarejestrowanie w Europie i USA wismodegibu - pierwszego drobnocząsteczkowego inhibitora szlaku Hedgehog - stanowiło milowy krok w terapii pacjentów z miejscowo zaawansowanym BCC (laBCC) i przerzutowym BCC (mBCC), u których wyczerpano lub nie ma możliwości leczenia chirurgicznego i radioterapii, oraz $u$ chorych z genetycznie uwarunkowanym zespołem Gorlina-Goltza [3]. Wismodegib stosuje się doustnie w standardowej dawce $150 \mathrm{mg} /$ dobę do momentu progresji lub toksyczności uniemożliwiającej kontynuację leczenia.

W badaniu klinicznym ERIVANCE, które było podstawą rejestracji wismodegibu, mediana czasu wolnego od progresji (progression-free survival - PFS) u chorych z mBCC wyniosła 9,3 miesiąca, a u chorych z laBCC (nieoperacyjnym, niekwalifikującym się do radioterapii) 12,9 miesiąca, natomiast mediana czasu trwania odpowiedzi na leczenie wyniosła odpowiednio 14,8 oraz 26,2 miesiąca. Odsetek odpowiedzi (objective response - OR) wśród pacjentów z laBCC $(47,6 \%)$ był nieco wyższy niż wśród pacjentów z mBCC $(33,3 \%)$ [38].

U pacjentów z zespołem Gorlina-Goltza lek ten znacząco ograniczył pojawianie się nowych BCC $\mathrm{w}$ grupie otrzymującej wismodegib w porównaniu z grupą otrzymującą placebo. U żadnego z pacjentów przyjmujących lek nie zaobserwowano progresji BCC, a u części chorych wystąpiła nawet całkowita remisja kliniczna zmian nowotworowych [39]. Do najczęstszych działań niepożądanych związanych z terapią wismodegibem należą: skurcze mięśni, zaburzenia smaku, łysienie, zmniejszenie masy ciała, nudności i biegunka [3, 38, 39].

W Polsce od stycznia 2017 roku wismodegib jest dostępną opcją terapeutyczną w ramach programu lekowego NFZ dla pacjentów z przerzutowym lub miejscowo zaawansowanym BCC niespełniającym kryteriów leczenia chirurgicznego oraz radioterapii. Innym drobnocząsteczkowym inhibitorem szlaku Hedgehog, zarejestrowanym w Stanach Zjednoczonych, jest sonidegib.

\section{Nowe perspektywy}

Aktualnie trwają badania oceniające zastosowanie wismodegibu $\mathrm{w}$ terapii neoadiuwantowej $\mathrm{u}$ pacjentów z miejscowo zaawansowanymi postaciami BCC (badanie VISMONEO), a także nad przezwyciężaniem mechanizmów oporności na terapię inhibitorami szlaku Hedgehog [40].

Wstępne wyniki wykazują, że przedoperacyjne zastosowanie wismodegibu zmniejsza wymiary nowo- 
Table 2. Recommended methods for observation of patients with various types of basal cell carcinoma (BCC), with a genetic syndrome predisposing him/her to BCC development, and during chronic immunosuppression

\begin{tabular}{|c|c|c|c|}
\hline \multirow[t]{2}{*}{ Clinical case } & \multicolumn{3}{|c|}{ Recommended observation } \\
\hline & $\begin{array}{c}\text { Year-long } \\
\text { photoprotection }\end{array}$ & Self-control & Dermatology exam and dermoscopy \\
\hline BCC in history & X & $X$ & $\begin{array}{l}\text { Every } 3 \text { months for the first } 3 \text { years; then every } \\
\qquad 6-12 \text { months }\end{array}$ \\
\hline $\begin{array}{l}\text { Patient with a genetic syndrome } \\
\text { predisposing him/her to BCC } \\
\text { development }\end{array}$ & $X$ & $x$ & Every $3-6$ months \\
\hline $\begin{array}{l}\text { Patients during chronic } \\
\text { immunosuppression }\end{array}$ & $x$ & $X$ & $\begin{array}{l}\text { Every } 6-12 \text { months; in case skin cancer is } \\
\text { diagnosed: every } 3-6 \text { months }\end{array}$ \\
\hline
\end{tabular}

Tabela 2. Zalecane metody obserwacji pacjentów z różnymi postaciami raka podstawnokomórkowego (BCC), z zespołem genetycznym predysponującym do rozwoju nowotworów skóry oraz w trakcie przewlekłej immunosupresji

\begin{tabular}{|c|c|c|c|}
\hline \multirow[t]{2}{*}{ Przypadek kliniczny } & \multicolumn{3}{|c|}{ Zalecana obserwacja } \\
\hline & $\begin{array}{c}\text { Całoroczna } \\
\text { fotoprotekcja }\end{array}$ & Samokontrola & Badanie dermatologiczne i dermoskopowe \\
\hline BCC w wywiadzie & X & $X$ & $\begin{array}{c}\text { Co } 3 \text { miesiące przez pierwsze } 3 \text { lata, następnie co } \\
\text { 6-12 miesięcy }\end{array}$ \\
\hline $\begin{array}{l}\text { Chory z zespołem genetycznym } \\
\text { predysponującym do rozwoju } \\
\text { BCC }\end{array}$ & 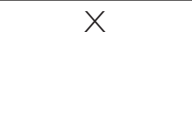 & $x$ & Co 3-6 miesięcy \\
\hline $\begin{array}{l}\text { Pacjenci w trakcie przewlekłej } \\
\text { immunosupresji }\end{array}$ & $X$ & $\mathrm{X}$ & $\begin{array}{c}\text { Co 6-12 miesięcy; w przypadku stwierdzenia raka } \\
\text { skóry co 3-6 miesięcy }\end{array}$ \\
\hline
\end{tabular}

tworu, co w wyjątkowych przypadkach umożliwia przeprowadzenie zabiegu chirurgicznego w miejscowo zaawansowanych BCC [40].

\section{OBSERWACJA PO ZAKOŃCZONYM LECZENIU ONKOLOGICZNYM}

U pacjentów, u których doszło do rozwoju BCC, wskazany jest długotrwały nadzór po zakończeniu leczenia. Dotyczy to szczególnie pacjentów ze zmianami o wysokim ryzyku nawrotów. Istotną rolę w opiece nad pacjentami z BCC po zakończonej terapii onkologicznej odgrywa również edukacja w zakresie całorocznej ochrony przed słońcem (preparaty SPF 30-50+) oraz znaczenia profilaktyki wtórnej, obejmującej między innymi regularne samodzielne badanie skóry przynajmniej raz w miesiącu [4].

Pierwsze 2 lata obserwacji są najbardziej krytyczne, dlatego pacjenci powinni w tym czasie być poddawani regularnym kontrolnym badaniom dermatologicznym z oceną dermoskopową (tab. 2).

\section{PODSUMOWANIE}

Należy pamiętać, że w każdym przypadku decyzje diagnostyczne i terapeutyczne podejmuje lekarz w porozumieniu z pacjentem, kierując się współczesną wiedzą medyczną oraz potencjalną skutecznością i profilem bezpieczeństwa, które mogą uzasadniać wybór danej opcji leczniczej w konkretnej sytuacji 
klinicznej. Przedstawione w tym opracowaniu metody leczenia stanowią jedynie zalecenia o charakterze ogólnym. Niniejszy artykuł nie stanowi rekomendacji Polskiego Towarzystwa Dermatologicznego dla żadnego konkretnego produktu leczniczego, wyrobu medycznego lub producenta.

\section{KONFLIKT INTERESÓW}

Autorzy nie zgłaszają konfliktu interesów.

\section{References}

Piśmiennictwo

1. Apalla Z., Lallas A., Sotiriou E., Lazaridou E., Ioannides D.: Epidemiological trends in skin cancer. Dermatol Pract Concept 2017, 7, 1-6.

2. Kim J.Y.S., Kozlow J.H., Mittal B., Moyer J., Olencki T., Rodgers P., et al.: Guidelines of care for the management of basal cell carcinoma. J Am Acad Dermatol 2018, 78, 560-578.

3. Bichakjian C., Olencki T., Aasi S., Alam M., Andersen J., Blitzblau R., et al.: Basal Cell Carcinoma, NCCN Clinical Practice Guidelines in Oncology wersja 1.2018. www. nccn.org (2018).

4. Rutkowski P., Owczarek W., Nejc D., Jeziorski A., Wysocki W.M., Słowińska M., et al.: Skin carcinomas. Oncol Clin Pract 2018, 14, 129-147.

5. Lomas A., Leonardi-Bee J., Bath-Hextall F.: A systematic review of worldwide incidence of nonmelanoma skin cancer. Br J Dermatol 2012, 166, 1069-1080.

6. Didkowska I., Wojciechowska U., Zatoński W.: Nowotwory złośliwe w Polsce w 2011 roku. Ministerstwo Zdrowia, Warsaw 2013.

7. Losquadro W.: Anatomy of the skin and the pathogenesis of nonmelanoma skin cancer. Facial Plast Surg Clin N Am 2017, 25, 283-289.

8. Krajowy Rejestr Nowotworów. www.onkologia.org.pl; available at: September 2018.

9. Bonerandi J.J., Beauvillain C., Caquant L., Chassagne J.F., Chaussade V., Clavère P., et al.: Guidelines for the diagnosis and treatment of cutaneous squamous cell carcinoma and precursor lesions. J Eur Acad Dermatol 2011, 25 Suppl. 5, 1-51.

10. Trakatelli M., Morton C., Nagore E., Ulrich C., Del Marmol V., Peris K., et al.: BCC subcommittee of the Guidelines Committee of the European Dermatology Forum. Update of the European guidelines for basal cell carcinoma management. Eur J Dermatol 2014, 24, 312-329.

11. Fahradyan A., Howell A.C., Wolfswinkel E.M., Tsuha M., Sheth P., Wong A.K.: Updates on the management of non-melanoma skin cancer (NMSC). Healthcare (Basel) 2017, 5, pii: E82.

12. Crowson A.N.: Basal cell carcinoma: clinical features, histology, and biology. In: A.N. Crowson, C. Magro, M.C. Mihm Jr (eds.). Biopsy Interpretation of the Skin: Primary Non-Lymphoid Cutaneous Neoplasia. Lippincott Williams Wilkins, Philadelphia, 2010, 199-234.

13. Lo Muzio L.: Nevoid basal cell carcinoma syndrome (Gorlin syndrome). Orphanet J Rare Dis 2008, 3, 32.

14. Ng J.M., Curran T.: The Hedgehog's tale: developing strategies for targeting cancer. Nat Rev Cancer 2011, 11, $493-501$.

15. Rutkowski P., Jassem J., Krzakowski M.: Złośliwe nowotwory skóry. Via Medica, Gdansk 2014.

16. Ciazynska M., Nartbutt J., Wozniacka A., Lesiak A.: Trends in basal cell carcinoma incidence rates: a 16-year retrospective study of a population in central Poland. Adv Dermatol Allergol 2018, 35, 47-52.

17. Felder S., Rabinovitz H., Oliviero M., Kopf A.: Dermoscopic differentation of a superficial basal cell carcinoma and squamous cell carcinoma in situ. Dermatol Surg 2006, 32, 423-425.

18. Argenziano G., Zalaudek I., Giacomel J.: Preface. Dermoscopy. Dermatol Clin 2013, 31, XIII-XIV.

19. Lallas A., Zalaudek I.: Dermoscopy in general dermatology. Dermatol Clin 2013, 31, 679-694.

20. Wozniak-Rito A., Zalaudek I., Rudnicka L.: Dermoscopy of basal cell carcinoma. Clin Exp Dermatol 2018, 43, $241-247$.

21. Lallas A., Tzellos T., Kyrgidis A., Apalla Z., Zalaudek I., Karatolias A., et al.: Accuracy of dermoscopic criteria for discriminating superficial from other subtypes of basal cell carcinoma. J Am Acad Dermatol 2014, 70, 303-311.

22. Lallas A., Apalla Z., Argenziano G., Longo C., Moscarella E., Specchio F., et al.: The dermatoscopic universe of basal cell carcinoma. Dermatol Pract Concept 2014, 4, 11-24.

23. Giacomel J., Lallas A., Argenziano G., Reggiani C., Piana S., Apalla Z., et al.: Dermoscopy of basosquamous carcinoma. Br J Dermatol 2013, 169, 358-364.

24. Navarrete-Dechent C., Bajaj S., Marchetti M.A., Rabinovitz H., Dusza S.W., Marghoob A.A.: Association of shiny white blotches and strands with nonpigmented basal cell carcinoma: evaluation of an additional dermoscopic diagnostic criterion. JAMA Dermatol 2016, 152, 546-552.

25. Lallas A., Argenziano G., Kyrgidis A., Apalla Z., Moscarella E., Longo C., et al.: Dermoscopy uncovers clinically undetectable pigmentation in basal cell carcinoma. Br J Dermatol 2014, 170, 192-195.

26. Longo C., Lallas A., Kyrgidis A., Rabinovitz H., Moscarella E., Ciardo S., et al.: Classifying distinct basal cell carcinoma subtype by means of dermatoscopy and reflectance confocal microscopy. J Am Acad Dermatol 2014, 71, 716-724.

27. Wilder R.B., Kittelson J.M., Shimm D.S.: Basal cell carcinoma treated with radiation therapy. Cancer 1991, 68, $2134-2137$.

28. Wilder R.B., Shimm D.S., Kittelson J.M.: Recurrent basal cell carcinoma treated with radiation therapy. Arch Dermatol 1991, $127,1668-1672$. 
29. Childers B.J., Goldwyn R.M., Ramos D., Chaffey J., Harris J.R.: Long-term results of irradiation for basal cell carcinoma of the skin of the nose. Plast Reconstr Surg 1994, 93, 1169-1173.

30. Hernandez-Machin B., Borrego L., Gil-Garcia M., Hernandez B.H.: Office-based radiation therapy for cutaneous carcinoma: evaluation of 710 treatments. Int J Dermatol 2007, 46, 453-459.

31. Quirk C., Gebauer K., De'Ambrosis B., Herbert B., Slade H.B., Meng T.C.: Sustained clearance of superficial basal cell carcinomas treated with imiquimod cream 5\%: results of a prospective 5-year study. Cutis 2010, 85, 318-324.

32. Arits A.H., Mosterd K., Essers B.A., Spoorenberg E., Sommer A., De Rooij M.J., et al.: Photodynamic therapy versus topical imiquimod versus topical fluorouracil for treatment of superficial basal-cell carcinoma: a single blind, non-inferiority, randomised controlled trial. Lancet Oncol 2013, 14, 647-654.

33. Savoia P., Deboli T., Previgliano A., Broganelli P.: Usefulness of photodynamic therapy as a possible therapeutic alternative in the treatment of basal cell carcinoma. Int J Mol Sci 2015, 16, 23300-23317.

34. Stebbins W.G., Hanke C.W.: MAL-PDT for difficult to treat nonmelanoma skin cancer. Dermatol Ther 2011, $24,82-93$.

35. Fantini F., Greco A., Del Giovane C., Cesinaro A.M., Venturini M., Zane C.: Photodynamic therapy for basal cell carcinoma: clinical and pathological determinants of response. J Eur Acad Dermatol Venereol 2011, 25, 896-901.

36. Roozeboom M.H., Arits A.H., Nelemans P.J., Kelleners-Smeets N.W.: Overall treatment success after treatment of primary superficial basal cell carcinoma: a systematic review and meta-analysis of randomized and nonrandomized trials. Br J Dermatol 2012, 167, 733-756.

37. Roozeboom M.H., Nelemans P.J., Mosterd K., Steijlen P.M., Arits A.H., Kelleners-Smeets N.W.: Photodynamic therapy vs. topical imiquimod for treatment of superficial basal cell carcinoma: a subgroup analysis within a noninferiority randomized controlled trial. Br J Dermatol 2015, 172, 739-745.

38. Sekulic A., Migden M.R., Oro A.E., Dirix L., Lewis K.D., Hainsworth J.D., et al.: Efficacy and safety of vismodegib in advanced basal-cell carcinoma. N Engl J Med 2012, 366, 2171-2179.

39. Tang J.Y., Mackay-Wiggan J.M., Aszterbaum M., Yauch R.L., Lindgren J., Chang K., et al.: Inhibiting the hedgehog pathway in patients with the basal-cell nevus syndrome. N Engl J Med 2012, 366, 2180-2188.

40. Mortier L., Bertrand N., Basset-Seguin N., Saiag P., Dupuy A., Dalac-Rat S., et al.: Vismodegib in neoadjuvant treatment of locally advanced basal cell carcinoma: first results of a multicenter, open-label, phase 2 trial (VISMONEO study). J Clin Oncol 2018, 36, 9509-9509.

Received: 14.01.2019

Accepted: 30.01 .2019

Otrzymano: 14.01.2019 r

Zaakceptowano: 30.01.2019 r.

How to cite this article

Lesiak A., Czuwara J., Kamińska-Winciorek G., Kiprian D., MajJ., Owczarek W., Placek W., Rudnicka L., Rutkowski P., Sobjanek M., Sokołowska-Wojdyło M., Szepietowski J., Zegarska B., Zegarski W.: Basal cell carcinoma. Diagnostic and therapeutic recommendations of the Polish Dermatological Society. Dermatol Rev/Przegl Dermatol 2019, 106, 107-126.

DOI: https://doi.org/10.5114/dr.2019.85572. 